\title{
NÃO DEIXAM DE SUSPIRAR PELA SUA LIBERDADE: \\ MOTINS DE INDIOS NO CEARÁ \\ E A FORMAÇAO DO ESTADO NO \\ BRASIL
}

(1) João Paulo Peixoto Costa

\section{RESUMO}

A atuação dos índios inseridos na formação do Estado brasileiro era, muitas vezes, caracterizada pelos administradores como "tumultos". Nesse clima de instabilidades, era assustador para as elites políticas das diversas regiões do Brasil o fato de novas ideias estarem sendo apropriadas pelas camadas subalternas. Indo além dos atos de nomear dos administradores, nosso objetivo é dar destaque aos possíveis significados daquela conjuntura para os indígenas nela envolvidos. Sua atuação nessa e em outras conjunturas girava em torno de sua liberdade e do combate à exploração de sua mão de obra.

\section{PALAVRAS-CHAVE}

Índios - independência - motins - liberdade - política - Ceará.

1 Instituto Federal do Piauí. Uruçuí - Piauí - Brasil.

2 Doutor em História Social pela UNICAMP. E-mail: joao.peixoto@ifpi.edu.br. 


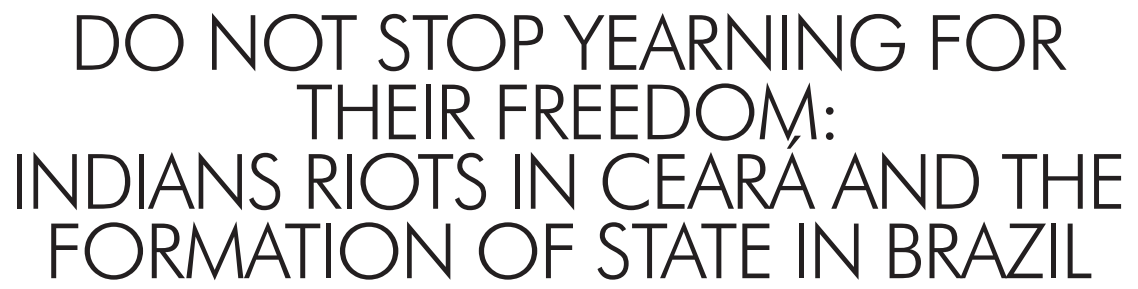

(D) João Paulo Peixoto Costa

\section{ABSTRACT}

The activity of the Indians inserted in the formation of the Brazilian State was often characterized by the administrators as "riots ". In this climate of instabilities, it was frightening to the political elites of the various regions of Brazil that new ideas were being appropriated by subaltern strata. Going beyond the acts of appointing of the administrators, our objective is to highlight the possible meanings of that conjuncture for the Indians involved in it. Their performance in this and other conjunctures revolved around his freedom and combating to the exploitation of his workmanship.

\section{KEYWORDS}

Indians - independence - riots - freedom - policy - Ceará. 


\section{Introdução}

1 pesar da riqueza da historiografia que busca reescrever a história dos processos que levaram à emancipação política 1 brasileira, há muito que avançar, principalmente quando o objetivo de análise é o seu desenrolar em outras regiões da antiga colônia lusitana que não sejam a capital. De acordo com João Paulo Pimenta, "a independência do Brasil nos é ainda praticamente desconhecida em muitas partes", por exemplo no Ceará 3 . Nesse caso, como notam Almir Oliveira e Keile Felix, percebe-se o quanto a capitania foi marcada pela falta de consensos e como os grupos locais tomavam por base o debate nacional, buscando legitimações a partir da defesa de projetos políticos próprios ${ }^{4}$. As elites políticas cearenses, por exemplo, se dividiam entre as de Fortaleza - apoiadoras do liberalismo das Cortes portuguesas - e as do interior - antilusitanas e fiéis ao projeto de dom Pedro I.

Além disso, são ainda recentes os estudos que se debruçam sobre a participação dos grupos marginalizados na construção do Estado brasileiro - como negros livres, escravos, mestiços, brancos pobres e índios - e seus lugares na nova nação. Para Natália Peres, desde o século XIX as grandes narrativas nacionais das antigas colônias europeias ressaltavam, de forma romântica, o papel dos heróis na construção das nações, geralmente associados às elites. Essa tendência se transformou com a atuação dos historiadores marxistas e, posteriormente, graças aos chamados subaltern studies, que deram relevo aos grupos subalternos nesses eventos. Todavia, não se trata apenas de "lembrar" dos dominados, mas reescrever essas histórias a partir

3 PIMENTA, João Paulo Garrido. A independência do Brasil e o liberalismo português: um balanço da produção acadêmica. Revista de História Ibero-americana, Madri, v. 1, n. 1, p. 90, 2008.

4 OLIVEIRA, Almir Leal de. A construção do Estado nacional no Ceará na primeira metade do século XIX: autonomias locais, consensos políticos e projetos nacionais. In: OLIVEIRA, Almir Leal de; BARBOSA, Ivone Cordeiro (org.). Leis provinciais: Estado e cidadania (1835-1861). Tomo I. Fortaleza: INESP, 2009. p. 20-21. FELIX, Keile Socorro Leite. Espíritos inflamados: a construção do Estado nacional brasileiro e os projetos políticos no Ceará (1817-1840). Dissertação (Mestrado) - Universidade Federal do Ceará, 2010. p. 15. 
de uma via de mão dupla na qual, além dos dominadores, os setores subordinados atuavam movidos por interesses próprios 5 . No caso da participação das populações indígenas, os estudos que as incluem "apenas começam a receber os primeiros tratamentos".

Índios, negros, mestiços e pobres não necessariamente compartilhavam os objetivos de seus possíveis aliados apenas enquanto peças de manobra do "recrutamento de gente mais pobre"7, como se seguissem cegamente as lideranças que os incitavam. Histórias de tumultos, revoltas e manifestações organizadas por índios ressaltam o poder que tinham de se envolver com outros grupos étnicos, de interpretar os eventos que explodiam nos centros de governo do Ceará e do Brasil e de lutar a partir de suas prioridades. $\mathrm{O}$ que estava em jogo não era somente a união ou não da antiga colônia ao império lusitano: as transformações em curso eram decisivas na redefinição da relação dos grupos sociais entre si.

Seguindo as provocações de Bert Barickman, é preciso considerar a relevância da participação dos índios na formação do Estado nacional brasileiro ${ }^{8}$. Protagonizaram movimentos em que se posicionaram a respeito das leis e das novas conjunturas políticas, mesmo em 1821, durante a reunião das Cortes de Lisboa, quando "tudo parecia despedaçar-se”, como afirma Magda Ricci ${ }^{9}$. Assim como os escravos de São Paulo estudados pela autora, que forjavam novos significados para a liberdade durante os debates da constituição portuguesa ${ }^{10}$, também os indígenas não ficaram passivos diante de mudanças tão perceptí-

5 PERES, Natalia Sobrevilla. Introduction: Identity and subalterns actors in the wars of independence. Estudios Interdisciplinarios de América Latina y el Caribe, Tel Aviv, v. 22, n. 1, p. 9-12, 2011. 6 PIMENTA, João Paulo Garrido. Op. Cit., p. 84-85.

7 FELIX, Keile Socorro Leite. Op. Cit., p. 74.

8 BARICKMAN, Bert J. "Tame Indians", "wild heathens" and settlers in southern Bahia in the late eighteenth and early nineteenth centuries. The Americas, Cambridge, v. 51, n. 3, p. 325, 1995.

9 RICCI, Magda Maria de Oliveira. Nas fronteiras da independência: um estudo sobre os significados da liberdade na região de Itu (1779-1822). Dissertação (Mestrado) - Universidade Estadual de Campinas, 1993. p. 240.

10 Ibid., p. 223-226. 
veis e imprevisíveis, que poderiam afetar de diversas maneiras suas vidas. A transferência da Corte portuguesa para a América em 1808 foi uma delas, ao "avivar entre os índios a figura do rei, longamente trabalhada no imaginário dessas populações, como um senhor todo-poderoso a quem deviam obediência”, como explicam Dantas, Sampaio e Carvalho ${ }^{11}$. Por isso que o retorno forçado de dom João VI em 1821 provocou tanta agitação, somente acalmada com a aclamação de dom Pedro I como imperador do Brasil no ano seguinte.

Em contrapartida, a "população pobre e desvalida estava sempre presente" nos movimentos que caracterizaram este período, "conduzindo conjunta e efetivamente os fatos"12. A exclusão dos setores marginais da nova nação não pode ser vista como uma atitude consensual também por conta das próprias ações e reivindicações desses grupos na tessitura e desenrolar dos eventos. No Ceará, a mobilização de índios em 1817 foi intensa, caracterizando não apenas seu papel de relevância para o Estado naquele contexto, mas também suas capacidades de leitura e atuação, mesmo depois do fim dos confli$\operatorname{tos}^{13}$. Durante a década de 20 do século XIX, a população indígena na província também se fez presente em diversos eventos marcados pela ebulição política.

Aqui, desde o início, é preciso enfrentar o desafio já explicitado por Carlo Ginzburg em sua reflexão sobre os "intermediários" no processo de análise histórica: aqueles que produziam os documen$\operatorname{tos}^{14}$. No caso proposto, a atuação dos índios inseridos na formação

11 DANTAS, Beatriz; SAMPAIO; José Augusto; CARVALHO; Maria do Rosário. Os povos indígenas no nordeste brasileiro: um esboço histórico. In: CUNHA, Manuela Carneiro da. História dos índios no Brasil. São Paulo: Companhia das Letras, 1992. p. 450.

12 RIBEIRO, Gladys Sabina. O desejo de liberdade e a participação de homens livres pobres e "de cor" na independência do Brasil. In: Caderno Cedes, Campinas, v. 22, n. 58, p. 29-30, 2002.

13 COSTA, João Paulo Peixoto. Disciplina e invenção: civilização e cotidiano indígena no Ceará. Teresina: EDUFPI, 2015. p. 287-304.

14 GINZBURG, Carlo. Our words, and theirs: a reflexion on the historian's craft, today. In: FELLMAN, Susanna; RAHIKAINEN, Marjatta. Quest of theory, method and evidence. Cambridge: Cambridge Scholars Publishing, 2012. p. 106-107. 
do Estado brasileiro era muitas vezes caracterizada pelos administradores como "tumultos". Nesse clima de instabilidades, era assustador para as elites políticas das diversas regiões do Brasil o fato de novas ideias estarem sendo apropriadas pelas camadas subalternas, como observa André Roberto Machado em relação aos indígenas ${ }^{15}$. Indo além dos atos de nomear dos administradores, nosso objetivo é dar destaque aos possíveis significados daquela conjuntura para os índios nela envolvidos.

\section{Os índios no Ceará e a constituição portuguesa}

A maior parte da população indígena do Ceará no início dos oitocentos habitava as povoações e vilas de índios pombalinas: eram elas Soure (atual Caucaia), Arronches (atual bairro da Parangaba, em Fortaleza), Messejana (bairro de Fortaleza), Monte-Mor Novo (atual Baturité) e Vila Viçosa (atual Viçosa do Ceará). As povoações correspondiam a São Pedro de Baepina (atual Ibiapina) no município de Vila Viçosa, Almofala (atual aldeia da etnia tremembé, em Itarema) no território de Sobral e Monte-mor Velho (atual Pacajús), pertencente a Aquiraz ${ }^{16}$.

Em menos de 30 anos após a revogação do Diretório - mesmo com a continuação de seu uso no Ceará -, os indígenas se encontravam na iminência de serem enquadrados por uma legislação. Como consequência, os ânimos se encontravam agitados, provocando manifestações nascidas da incerteza do que estava por vir. Se suas prerrogativas não eram plenamente garantidas com a lei pombalina, as notícias de uma nova Constituição para o império português, que diminuiria o poder do rei e o levaria de volta para a Europa, poderia

15 MACHADO, André Roberto de Arruda. A quebra da mola real das sociedades: a crise política do antigo regime português na província do Grão-Pará (1821-25). Tese (Doutorado) - Universidade de São Paulo, 2006. p. 98-99.

16 Na região do Cariri, na fronteira cearense com Pernambuco e Paraíba, também viviam os chamados "gentios", povos nômades de variados etnônimos, como oés, humões, xocós e quipapazes. 
significar o fim de uma proteção já distanciada e o aumento da força dos colonos sobre eles.

No final do ano de 1821, chegaram à Junta Provisória de Governo do Ceará notícias sobre o suposto envolvimento dos índios de Almofala em um levante de negros, diante do qual foi passada ordem ao sargento-mor Francisco de Sales Gomes de "observar seu movimentos, [...] e não perder um instante em dar em tudo parte a este governo"17. Foi também questionado ao comandante de Monte-mor Velho o porquê de ter armado os índios de seu comando com arcos e flechas em setembro desse ano, durante as eleições de comarca na capital ${ }^{18}$. Pelas informações da documentação, não é possível ter plena certeza se tais movimentações se relacionavam diretamente com a reunião das Cortes em Lisboa, mas certamente contribuíram para o aumento da tensão desse período, marcado pelo conturbado contexto de criação da própria Junta Provisória.

Desde a promulgação do decreto de 24 de fevereiro, por meio do qual dom João VI aprovava o texto constitucional que se fazia em Portugal $^{19}$, e com as notícias de criação de juntas de governo em Pernambuco e Bahia, autoridades militares e políticas do Ceará buscaram proceder de igual maneira na capitania. Suas ações eram motivadas pela oposição ao então governador Francisco Alberto Rubim, por conta de suas ações no sentido de restringir o acesso indiscriminado à mão de obra indígena, "que até então o Diretório lhes facultava, [...] sem haver ordem régia para isso"20. Os comentários dos injuriados vereadores de Fortaleza expressam sua dependência em relação

17 Da Junta Provisória de Governo do Ceará a Francisco de Sales Gomes. Fortaleza, 1 de dezembro de 1821. Arquivo Nacional (AN), série Interior - Negócios de Províncias (AA), IJJ9 576, p. 53.

18 Da Junta Provisória de Governo do Ceará ao comandante de Monte-mor Velho. Fortaleza, 15 de novembro de 1821. AN, AA, IJJ9 576, p. 66.

19 Decreto de 24 de fevereiro de 1821. Aprova a Constituição que se está fazendo em Portugal, recebendo-a ao Reino do Brasil e mais domínios. Palácio do Rio de Janeiro. Disponível em: $<$ https:// bit.ly/2VTS2Ke>. Acesso em: 2 jul. 2015.

20 Dos vereadores da câmara de Fortaleza ao rei dom João VI. Fortaleza, 17 de novembro de 1821. AN, AA, IJJ9 513. 
ao trabalho dos índios, bem como a falta de qualquer determinação do rei, até aquele período, que anulasse a lei pombalina em território cearense.

O filho do governador, Braz da Costa Rubim, também fez considerações sobre os acontecimentos em sua Memória sobre a Revolução no Ceará de 1821. O culto católico que, segundo ele, poderia contribuir para arrefecer os ânimos, "estava, se não de todo desprezado, quase indiferente, mormente nas povoações dos índios, gente ainda inculta, e por consequência sem fé, sem consciência, sem temor de Deus"21. O autor ignorou - talvez por não ter sido contemporâneo - as diversas manifestações dos índios em prol da melhoria de suas freguesias, ${ }^{22}$ bem como sua mobilização diante dos acontecimentos que narrou em seguida. Utilizando linguagem diferenciada ao destacar a prudência e "firme opinião" de seu pai, relatou que, na madrugada de 14 de abril, pressionado por manifestantes amotinados em frente à sua residência, Francisco Rubim decidiu, entre outras coisas, jurar a constituição que se fizesse em Portugal, sem formar, contudo, uma junta governativa. Dois dias depois, alguns "malévolos espalharam o boato de que, às instigações do governador, os índios se reuniam com hostil intento de encaminhar-se depois à Fortaleza e prender o batalhão de linha que tinha tomado a iniciativa na revolução"23.

Os membros da câmara de Fortaleza, em vereação enviada ao rei em novembro do mesmo ano, também contaram sobre a "notícia de que os índios se ajuntavam para prender o batalhão", segundo eles na "tarde do dia 15". Sem chamar os autores do boato de "malévolos", disseram ainda que o governador lançou mão da ocasião para pro-

21 RUBIM, Braz da Costa. Memória sobre a revolução do Ceará em 1821. Revista do Instituto Histórico e Geográfico do Brasil, Rio de Janeiro, tomo XXIX, segunda parte, p. 206-207, 1866.

22 COSTA, João Paulo Peixoto. Op. Cit., p. 150-166.

23 RUBIM, Braz da Costa. Op. Cit., p. 215. Também sobre o boato da reunião dos índios no Ceará no contexto da reunião das Cortes de Lisboa, vide: VARNHAGEN, Francisco Adolfo de. História da independência do Brasil até ao reconhecimento pela antiga metrópole, compreendendo, separadamente, a dos sucessos ocorridos em algumas províncias até essa data. Revista do Instituto Histórico e Geográfico Brasileiro, Rio de Janeiro, tomo LXXXIX, p. 448, 1916. 
mover uma "intriga para dividir a tropa do povo", provocando uma "tão relaxada insubordinação que todos temiam a sua desgraça"24. Fica claro o esforço de ambas as partes, seja de Braz Rubim como dos vereadores, em se utilizar da difusão do rumor em seus relatos para promover ou detratar quem lhes interessava.

O comum nas duas versões era o receio que havia, tanto no governo quanto em outros setores da população, uma possível reação dos índios. Mesmo que fossem geralmente descritos como apáticos, alheios ao mundo ou "sem consciência", era conhecida a fidelidade das comunidades indígenas à Coroa e sua determinação em defendê-la, como ficara claro, anos antes, na Revolução Pernambucana. Por isso, mesmo não sendo possível ter certeza se os índios realmente planejavam confrontar os militares que pressionaram o governador, não é possível afirmar categoricamente que o "povo" não compreendia se deveria apoiar ou não o movimento vintista, como faz Keile $\mathrm{Felix}^{25}$. A respeito dos indígenas, era previsível que se posicionassem de maneira firme e perigosa diante da nova Constituição e de eventos políticos que ameaçavam a soberania de seu rei e sua própria segurança.

Não faltaram exemplos no Brasil da atuação política dos índios no contexto da independência brasileira. Para além das discussões nas Cortes de Lisboa sobre a questão indígena, Julio Sánchez Gómez chama atenção para casos de índios que, agindo coletivamente, se dirigiram à Assembleia Constituinte portuguesa demandando direitos violados ou pedindo modificações em seus estatutos legais. O autor cita a representação dos principais das margens do rio Tocantins, em dezembro de 1821, pedindo a propagação da religião e a restituição de sua liberdade e a queixa de índios de Extremoz, no Rio Grande do Norte, contra seu pároco ${ }^{26}$. Como se observa, boa parte

24 Dos vereadores da câmara de Fortaleza ao rei dom João VI. Fortaleza, 17 de novembro de 1821.

AN, AA, IJJ9 513.

25 FELIX, Keile Socorro Leite. Op. Cit., p. 80.

26 GÓMEZ, Julio Sánchez. Invisibles y olvidados: indios e independencia de Brasil. Studia Historica.

Historia Contemporánea, n. 27, p. 250-251, 2009. 
da atuação dos índios nessa e em outras conjunturas girava em torno de sua liberdade e do combate à exploração de sua mão de obra. André Roberto Machado afirma que, com o avanço do debate sobre a nova constituição a ser promulgada no império português, cada vez mais os índios "foram invocando a condição de homens livres para reivindicar suas garantias constitucionais, especialmente como forma de minar as estruturas que os obrigavam ao trabalho compulsório"27.

Entretanto, ainda são poucos os estudos que tratam da situação indígena no contexto em questão, concentrando-se a maioria na situação dos chamados "bravios"28 ou na construção da memória e

27 MACHADO, André Roberto de Arruda. Op. Cit., p. 108.

28 BARICKMAN, Bert J. Op. Cit., p. 325-368. LANGFUR, Hal. The forbidden lands: colonial identity, frontier violence, and the persistence of Brazil's Eastern indians, 1750-1830. Stanford: Stanford University Press, 2006. LEMOS, Marcelo Sant’ana. O índio virou pó de café? A resistência dos índios Coroados de Valença frente à expansão cafeeira do Vale do Paraíba (1788-1836). Dissertação (Mestrado em História) - Universidade do Estado do Rio de Janeiro, Rio de Janeiro, 2004. MATTOS, Izabel Missagia. "Civilização" e "revolta": povos botocudos e indigenismo missionário na província de Minas. Tese (Doutorado em Ciências Sociais) - Universidade Estadual de Campinas, Campinas, 2002. MOREIRA, Vânia Maria Losada. Autogoverno e economia moral dos índios: liberdade, territorialidade e trabalho (Espírito Santo, 1798-1845). Revista de História, n. 166, p. 223-243, 2012. MALHEIROS, Márcia. Homens da fronteira: índios e capuchinhos na ocupação dos Sertões do Leste, do Paraíba ou Goytacazes (séculos XVIII e XIX). Tese (Doutorado em História) - Universidade Federal Fluminense, Niterói, 2008. MARINATO, Francieli Aparecida. Índios imperiais: os botocudos, os militares e a colonização do Rio Doce (Espírito Santo, 1824-1845). Dissertação (Mestrado em História Social das Relações Políticas) - Universidade Federal do Espírito Santo, Vitória, 2007. MOREL, Marco. Independência, vida e morte: os contatos com os Botocudo durante o Primeiro Reinado. Dimensões, v. 14, p. 91-113, 2002. PARAÍSO, Maria Hilda Baqueiro. O tempo da dor e do trabalho: a conquista dos territórios indígenas nos sertões do leste. Salvador: EDUFBA, 2014. SILVA, Natalia Moreira da. Papel de índio: políticas indigenistas na província de Minas Gerais e Bahia na primeira metade dos oitocentos (1808-1845). Dissertação (Mestrado em História) - Universidade Federal de São João Del-Rei, São João Del-Rei, 2012. SILVA, Tarcísio Glauco da. Junta de civilização e conquista dos índios e navegação do rio Doce: fronteiras, apropriação de espaços e conflitos (1808-1814). Tese (Doutorado História Social das Relações Políticas) Universidade Federal do Espírito Santo, Vitória, 2006. SPOSITO, Fernanda. Nem cidadãos, nem brasileiros: indígenas na formação do Estado nacional brasileiro e conflitos na província de São Paulo (1822-1845). São Paulo: Alameda, 2006. SOUZA, Almir Antônio de. Armas, pólvoras e chumbo: a expansão luso-brasileira e os indígenas do planalto meridional na primeira metade do século XIX. Tese (Doutorado em História) - Universidade Federal de Santa Catarina, Florianópolis, 2012. 


\section{identidade nacional no primeiro reinado ${ }^{29}$. Outros pontos de interes- se vêm aparecendo em investigações dos últimos anos, como a rela- ção dos índios com o estatuto de "cidadãos"30 e a participação indíge- na nas lutas pela separação política brasileira e nos conflitos liberais oitocentistas $^{31}$.}

29 ALMEIDA, Maria Regina Celestino de. Comunidades indígenas e Estado nacional: histórias, memórias e identidades em construção (Rio de Janeiro e México - séculos XVIII e XIX). In: ABREU, Marta; SOIHET, Rachel; GONTIJO, Rebeca (org.). Cultura política e leituras do passado: Historiografia e ensino de História. Rio de Janeiro: Civilização Brasileira, 2007. LOURENÇO, Jaqueline. Um espelho brasileiro: visões sobre os povos indígenas e a construção de uma simbologia nacional do Brasil (1808-1831). Dissertação (Mestrado em História Social) - Universidade de São Paulo, São Paulo, 2010.

30 SANTOS, Raquel Dani Sobral. A construção do estatuto de cidadão para os índios do Grão-Pará (18081822). Dissertação (Mestrado em História Social) - Universidade de São Paulo, São Paulo. 2013. Vânia Moreira se utiliza dos conceitos de "cidanização" e "nacionalização" para tratar do processo de inclusão de índios na condição de cidadãos pertencentes ao Estado nacional brasileiro a partir da promulgação da Constituição de 1824. Cf. MOREIRA, Vânia Maria Losada. Autogoverno e economia moral dos índios, Op. Cit. p. 68-69. MOREIRA, Vânia Maria Losada. Indianidade, territorialidade e cidadania no período pós-independência - Vila de Itaguaí, 1822-1836. Diálogos Latinoamericanos, n. 18, p. 1-17, 2011.

31 CARVALHO, Marcus J. M. de. Os índios e o Ciclo das Insurreições Liberais em Pernambuco (1817-1848): ideologias e resistências. In: ALMEIDA, Luiz Sávio de; GALINDO, Marcos. Índios do Nordeste: temas e problemas. v. 3. Maceió: EDUFAL, 2002. FERREIRA, Lorena de Mello. São Miguel de Barreiros: uma aldeia indígena no Império. Dissertação (Mestrado em História) - Universidade Federal de Pernambuco, Recife, 2006. GARCIA, Elisa Frühauf. Dimensões da igualdade: os significados da condição indígena no processo de independência do Rio da Prata. In: Encontro Regional de História da Anpuh, 19., São Paulo. Anais... São Paulo: Anpuh, 2008. GÓMEZ, Julio Sánchez. Op. Cit., pp. 235-277. MACHADO, André Roberto de Arruda. Op. Cit. MELO, Karina Moreira Ribeiro da Silva e. A aldeia de São Nicolau do Rio Pardo: histórias vividas por índios guaranis (séculos XVIII e XIX). Dissertação (Mestrado em História) - Universidade Federal do Rio Grande do Sul, Porto Alegre, 2011. DANTAS, Mariana Albuquerque. Dimensões da participação política indígena na formação do Estado nacional brasileiro: revoltas em Pernambuco e Alagoas (1817-1848). Tese (Doutorado em História) - Universidade Federal Fluminense, Niterói, 2015. DARÓZ, Carlos Roberto Carvalho. A milícia em armas: o soldado brasileiro da guerra de independência. Revista Brasileira de História Militar, v. 4, n. 11, p. 41-42, 2013. REGO, André de Almeida. Trajetórias de vidas rotas: terra, trabalho e identidade indígena na província da Bahia (1822-1862). Tese (Doutorado em História Social) - Universidade Federal da Bahia, Salvador, 2014. p. 53-54. GUERRA FILHO, Sérgio Armando Diniz. O povo e a guerra: participação das camadas populares nas lutas pela independência do Brasil na Bahia. Dissertação (Mestrado em História Social) - Universidade Federal da Bahia, Salvador, 2004. p. 115-117. 
As comunidades indígenas atuaram ao atenderem as chamadas de recrutamento diante de situações de conflito bélico, expressando seus interesses e manifestando fidelidade aos projetos que consideravam vantajosos. Segundo André Roberto Machado, os índios no Pará participaram "ativamente da ebulição política do período". Compondo de forma majoritária as tropas e a força de trabalho na província e insatisfeitos com a exploração e os recrutamentos forçados no período da independência, os índios e outros grupos subordinados provocaram temor nas autoridades ${ }^{32}$, inclusive bradando contra o governo dos brancos ${ }^{33}$. Outro caso de participação indígena nas guerras de independência foi o dos xucurus e paritiós aldeados em Cimbres, Pernambuco. Para Marcus Carvalho, os índios se posicionaram contrariamente a poderosos locais, partidários da separação brasileira, porque havia tempos estes últimos buscavam tomar suas terras $^{34}$. Mariana Albuquerque Dantas também analisa o conflito de Cimbres, percebendo a inserção do posicionamento político indígena "num quadro complexo de disputas locais pelas terras do aldeamento e por cargos políticos"35. Segundo a autora, os índios estavam "imersos em relações de violência, de recrutamento forçado e de tentativas de invasão de suas terras" com a câmara partidária da separação política brasileira, o que motivou sua aliança com os portugueses e a realização de levantes em defesa de dom João VI ${ }^{36}$.

Todos esses exemplos fazem parte de um contexto maior de "construção da liberdade" analisado por Gladys Ribeiro, quando diferentes setores sociais no Brasil "passaram a vislumbrar as possibilidades de um futuro promissor e a lutar passo a passo pelas suas

32 MACHADO, André Roberto de Arruda. Op. Cit., p. 165.

33 Ibid., p. 175.

34 CARVALHO, Marcus Joaquim Maciel de. Clientelismo e contestação: o envolvimento dos índios de Pernambuco nas brigas dos brancos na época da independência. In: MONTEIRO, John Manuel; AZEVEDO, Francisca Nogueira de. (org.). Confronto de culturas: confronto, resistência e transformação. São Paulo: EDUSP, 1997. p. 329-342.

35 DANTAS. Mariana Albuquerque. Op. Cit, p. 139.

36 Ibid., p. 143-146. 
libertações" ${ }^{37}$. Para os índios no Ceará, a luta por sua liberdade no contexto da independência do Brasil conectava referências muito antigas a perspectivas de futuro. Combatiam com temor de um possível retorno da escravidão vivida por seus antepassados e contra as explorações que cotidianamente sofriam. Percebiam este momento como uma oportunidade de lutarem por sua condição de vassalos livres.

\section{O motim dos indios de Maranguape}

O maior e mais bem documentado levante de índios no Ceará desse período aconteceu em Maranguape (à época, povoado pertencente ao município de Arronches, hoje emancipado), próximo a Fortaleza. Segundo Geraldo Nobre, o "acontecimento é deveras importante, não pelo vulto, mas pelas circunstâncias e consequências, ocorrido em um período agitado por mudanças institucionais de natureza jurídico política”. Mesmo tendo suscitado ações militares violentas e sérias preocupações no governo, a falta de vulto na ótica do autor se devia à condição étnica dos amotinados, cuja rebelião durou mais de um ano. Pelos escassos documentos de que dispunha Nobre, não era possível esclarecer "suficientemente os motivos do levantamento dos íncolas maranguapenses”, atribuído à expulsão do vigário Felipe Benício Mariz de Viçosa pelos índios da vila em julho de $1822^{38}$, caso que analisaremos em seguida. Contudo, as primeiras referências às tensões em Maranguape são do ano anterior, contemporâneas à reunião das Cortes em Lisboa. A ligação entre esses eventos políticos não foi suposta pelo autor.

Em 6 de outubro de 1821, chegou à sala do governador Francisco Alberto Rubim, através da câmara da vila de Arronches, a notícia de que na localidade de Maranguape o capitão Antônio José de Vas-

37 RIBEIRO, Gladys Sabina. A liberdade em construção: identidade nacional e conflitos antilusitanos no Primeiro Reinado. Tese (Doutorado) - Universidade Estadual de Campinas, Campinas, 1997. p. 336.

38 NOBRE, Geraldo. Os índios revoltosos na serra de Maranguape. Revista do Instituto do Ceará, Fortaleza, tomo CIX, p. 315-318, 1995. 
concelos teria espalhado que o objetivo da constituição portuguesa era cativar os índios, "e quanto às mais pessoas concede-lhes liberdade de obrar arbitrariamente sem que se possa conhecer das suas ações" 39 . Poucos dias depois, o governador, juntamente com o Conselho, confirmou que a câmara de Arronches estava "mal informada sobre a representação que fez". Ordenaram que, "à vista da inocência" de Vasconcelos, tornasse a "entrar no comando da povoação de Maranguape" e que, atendendo-se à ignorância dos camaristas, se lhe advertisse "para serem mais escrupulosas nas suas representações"40.

Apesar de não ser possível certificar a veracidade da denúncia, percebe-se a ligação da própria suspeita com a questão do uso da força de trabalho indígena por parte dos colonos. A acusação originou-se na câmara de uma vila de índios, cujos membros eram também indígenas e que, de alguma forma, perceberam o perigo que este tipo de boato poderia causar na população. Mesmo que a escravidão tivesse sido expressamente proibida desde a instituição do Diretório, o medo dela parecia ainda pairar na mente dos indígenas. Para os que sofriam abusos, esse medo nunca havia cessado por completo. Ou seja, o grande problema estava na falta de limites para as ações de proprietários que utilizavam seu trabalho, que poderiam ficar ainda mais frouxos com uma nova constituição.

As lembranças dos índios de contextos ancestrais em suas comunidades e a forma como agiam a partir delas em diferentes situações compunham sua "cultura histórica”. Maria Regina de Almeida a entende como "a compreensão e o posicionamento que os grupos têm a respeito de seu próprio passado e o uso que dele fazem, conforme necessidades do presente". A opressão e os abusos que sofriam não eram impedimentos para suas atuações: antes, era em resposta a eles que desenvolviam "suas próprias formas de agir politicamente e de

39 Do Conselho Consultivo do governo do Ceará à câmara da vila de Arronches. Fortaleza, 6 de outubro de 1821, Arquivo Público do Estado do Ceará (APEC), fundo Governo da Capitania (GC), livro 32, p. 03v.

40 Do Conselho Consultivo do governo do Ceará à câmara da vila de Arronches. Fortaleza, 15 de outubro de 1821, APEC, GC, livro 32, p. 04v. 
pensar sobre seu passado para operacionalizá-lo de acordo com seus objetivos do presente" ${ }^{\prime 1}$.

Em 27 de novembro, alguns dias após a deposição do governador Francisco Rubim, a Junta Provisória de Governo do Ceará lançou um edital acerca das tensões entre os moradores de Maranguape, "composta de naturais da vila de Arronches [índios] e de outros naturais ali estabelecidos com seu negócio e lavoura”. Segundo os membros do governo, a origem dos distúrbios havia sido algumas "palavras indiscretas" proferidas por não-índios, provocando reações nos indígenas "por falta de conhecimentos civis e políticos" e pela destruição de suas plantações por animais soltos dos extranaturais, apesar das proibições das leis municipais.

Mandamos e recomendamos a todos os sobreditos moradores de $\mathrm{Ma}$ ranguape que, como cidadãos que igualmente o são, vivam em paz e união, ficando na certeza de que obrando o contrário, procederemos contra eles com todo o rigor das leis e como perturbadores do sossego público, e, outrossim, mandamos a todos os que ali tiverem bois de carro e de açougue, que as conserve com pastos longe das lavouras, e aos que tiverem animais cavalares as façam pear, e aos que tiverem porcos e cabras as lancem para fora, ou conservem presos, aliás serão castigados na forma acima dita, e para que o referido chegue a notícia de todos, se mandou publicar o presente ${ }^{42}$.

No mesmo dia, ordens do governo foram enviadas para que se evitassem conflitos entre extranaturais e índios. Aos primeiros, que não perturbassem os indígenas, "assim de palavras como de ações, [...] no exercício de suas terras que por direito lhe pertencem"43. Para

41 ALMEIDA, Maria Regina Celestino de. O lugar dos índios na História entre múltiplos usos do passado: reflexões sobre cultura histórica e cultura política. In: SOIHET, Rachel; ALMEIDA, Maria Regina Celestino de; SÁ, Cecília; GONTIJO, Rebeca. Mitos, projeto e práticas políticas: memória e Historiografia. Rio de Janeiro: Civilização Brasileira, 2009. p. 210-211.

42 Edital. Fortaleza, 27 de novembro de 1821. AN, AA, IJJ9 576, p. 69v.

43 Da Junta Provisória de Governo do Ceará a Antônio José de Vasconcelos. Fortaleza, 27 de novembro de 1821. AN, AA, IJJ9 576, p. 70. 
os segundos, recomendou-se que reportassem qualquer queixa ao governo, "o qual estará sempre pronto para promover tudo quanto for a bem dos sobreditos índios"44.

O governo já percebia que a conjuntura das Cortes de Lisboa provocava interpretações diversas pelos diferentes setores sociais e buscava se precaver de consequentes distúrbios. Por um lado, a destruição das plantações indígenas era parte de um antigo processo que buscava inviabilizar a produção nas terras das vilas e, como consequência, legitimar a sua ocupação pelos colonos. De acordo com Bert Barickman e Fátima Lopes, a própria intensão do Diretório de criar um campesinato índio que pudesse abastecer o mercado colonial era ineficaz, tendo em vista a exploração de sua força de trabalho e a ocupação das terras ${ }^{45}$. A presença de animais nas terras indígenas de Maranguape se alinhava a essa estratégia que ganhava força nesta conjuntura.

As "palavras indiscretas" dos não-índios, por outro lado, tinham provável ligação com os boatos do mês anterior denunciados pela câmara de Arronches. Somadas, pareciam fazer parte de uma investida dos extranaturais no contexto do retorno de dom João VI para Portugal. Os índios, por sua vez, agiram vigorosamente diante da possível ameaça: embora o governo lhes atribuísse falta de conhecimento, percebiam o avanço sobre suas lavouras, o histórico de abusos que sofriam, a impunidade contra seus algozes e a ausência de seu protetor, transladado à força para o outro lado do oceano.

O alerta sobre os ânimos no povoado manteve-se no mês seguinte, com as investigações a respeito da família do índio Ângelo Manuel e a situação dos bananais dos indígenas ${ }^{46}$, provavelmente afe-

44 Da Junta Provisória de Governo do Ceará a Francisco José Pinheiro. Fortaleza, 27 de novembro de 1821. AN, AA, IJJ9 576, p. $71 v$.

45 BARICKMAN, Bert J. Op. Cit., p. 351. LOPES, Fátima Martins. Em nome da liberdade: as vilas de índio do Rio Grande do Norte sob o Diretório pombalino no século XVIII. Tese (Doutorado em História do Norte-Nordeste) - Universidade Federal de Pernambuco, Recife, 2005. p. 465.

46 Da Junta Provisória de Governo do Ceará a Francisco José Pinheiro. Fortaleza, 12 de dezembro de 1821. AN, AA, IJJ9 576, p. 82v. 
tados pelo gado dos vizinhos não-índios. Na véspera do Natal, tendo recebido um ofício de Pinheiro no dia 21, o governo ordenou-lhe as "providências que são do estilo, [...] sem, contudo, haver excesso de rondas que haja de motivar novidades, assim aos moradores como aos índios ${ }^{47}$. O resultado parece não ter sido satisfatório, atribuído a desavenças entre autoridades militares da região, e deram espaço à eclosão de distúrbios no Natal de 1821 em Maranguape, cujas motivações e outros detalhes não são claros na documentação ${ }^{48}$.

Em 7 de janeiro de 1822, o juiz de fora Jacinto Fernandes de Araújo foi acionado para proceder "contra os culpados, que desde já ficaram presos”. Dentre eles, o índio Lino José Batista, por dar uma facada em uma mulher ${ }^{49}$. Já nessa situação de tumulto, os índios, havia pouco vítimas de boatos e de destruição de suas lavouras, passaram a ser elementos perigosos. As causas dos distúrbios nem sequer mereceram ser registradas e a reação imediata do governo foi o encarceramento dos envolvidos. O governo se desfez da promessa de "promover tudo quanto for a bem dos índios" porque, mesmo em meio a um contexto de crise do Antigo Regime - quando o governo do Ceará, por meio do edital acima mencionado, chamava os habitantes da província de "cidadãos" -, a sociedade ainda era hierarquizada. Nela, além da economia das penas, que variava de acordo com os privilégios sociais do réu, como afirma Silvia Lara ${ }^{50}$, a própria definição de crime e culpa se dava de acordo com as origens étnicas e sociais dos autores do ato.

47 Da Junta Provisória de Governo do Ceará a Francisco José Pinheiro. Fortaleza, 23 de dezembro de 1821. AN, AA, IJJ9 576, p. 102v.

48 Da Junta Provisória de Governo do Ceará a Afonso José de Albuquerque. Fortaleza, 26 de dezembro de 1821. AN, AA, IJJ9 576, p. 105. Da Junta Provisória de Governo do Ceará a José Agostinho Pinheiro. Fortaleza, 26 de dezembro de 1821. AN, AA, IJJ9 576, p. $105 \mathrm{v}$.

49 Da Junta Provisória de Governo do Ceará a Jacinto Fernandes de Albuquerque. Fortaleza, 7 de janeiro de 1822. AN, AA, IJJ9 576, p. 121v.

50 LARA, Silvia Hunold. Introdução: ordenações filipinas. Livro V. São Paulo: Companhia das Letras, 1999. p. 40. 
Nesse clima de repressão, ainda no dia 7 de janeiro, a Junta informou ao diretor de Monte-mor Novo, Manuel Moreira Barros, que recebera o comandante dos índios da vila, Manoel Soares do Nascimento, dizendo que havia se ausentado "com receio que o prendessem" e que ignorava as desordens do dia 25. Diante disso, o governo lhe ordenou que "voltasse ao seu distrito e que fosse viver em paz" e, ao diretor, que o vigiasse "sobre seu viver, para ser castigado competentemente no caso de transgredir as ordens desta Junta e faltar ao que prometeu"51. O medo de Nascimento, que não foi à toa, é indício de que a situação dos índios passou a ser bastante desvantajosa. $O$ governo em questão foi o mesmo que obrigou o antigo governador Rubim a jurar a constituição portuguesa e agia violentamente contra qualquer manifestação de oposição às Cortes de Lisboa. Por conta dos acontecimentos em Maranguape e pelos índios já terem se mostrados insatisfeitos com as medidas, todos eles eram dignos de suspeita.

Meses se passaram desde os conflitos de dezembro sem qualquer informação sobre convulsões envolvendo o povo de Maranguape. Já em Viçosa, os índios entraram em confronto com o vigário Felipe Mariz, como vimos nos comentários de Geraldo Nobre, mas não o iniciaram necessariamente por conta da constituição portuguesa - já que os primeiros relatos falam exclusivamente de violências praticadas pelo religioso. Ainda assim, os distúrbios preocupavam o governo pelas ligações que poderiam ter com questões políticas e com os acontecimentos ocorridos próximos a Fortaleza. As medidas preventivas não conseguiram, porém, impedir que novas e mais intensas manifestações surgissem naquela região. Pouco menos de um ano depois dos primeiros boatos que assustaram os indígenas, em setembro de 1822 - durante os acontecimentos que levaram à independência do Brasil - tem-se a notícia de um

Tumulto dos índios e extranaturais da serra de Maranguape tendo ido um número de mais de seiscentos às fazendas do diretor geral o sargento-mor

51 Da Junta Provisória de Governo do Ceará a Manuel Moreira Barros. Fortaleza, 7 de janeiro de 1822. AN, AA, IJJ9 576, p. $122 \mathrm{~V}$. 
José Agostinho, e o juiz de fora pela lei Joaquim Lopes com ânimo de assassiná-los, e sempre roubaram as casas, dando gritos contra os europeus, e a favor da liberdade dos escravos. (grifos meus).

A sessão decidiu que se tomassem as "providências necessárias para a prisão dos revoltosos e para a segurança desta capital, e mais vilas imediatas, que estiveram em armas para repelir qualquer ataque repentino" 52 . Por se localizar a cerca de $30 \mathrm{~km}$ de Fortaleza, tais incidentes eram ameaças bastante perceptíveis para os que comandavam a, agora, província. O conteúdo de suas manifestações chama atenção tanto pelas reivindicações como pelos seus protagonistas: da maneira como expõe o documento, índios e não índios - desafetos até o ano anterior - pareciam gritar juntos contra os "irmãos" de outro continente, refazendo a fronteira político-identitária que os diferenciava. Se tal união, mesmo que momentânea, de fato aconteceu, denota o caráter fluido das fronteiras étnicas, que tem o "outro" como motor ${ }^{53}$ (nesse caso, a oposição aos europeus).

Os alvos do "tumulto" eram diretamente ligados aos índios: José Agostinho Pinheiro era o diretor geral e Joaquim Lopes de Abreu havia sido uma das autoridades protagonistas da ocupação da serra de Maranguape entre os séculos XVIII e XIX e das usurpações de terras indígenas na região. Além disso, os dois eram naturais de Portugal ${ }^{54}$,

52 Do Conselho Consultivo do governo do Ceará à câmara da vila de Arronches. Fortaleza, 23 de setembro de 1822, APEC, GC, livro 32, p. 29. Grifo meu.

53 BARTH, Fredrick. Grupos étnicos e suas fronteiras apud POUTIGNAT, Philippe; STREIFF-FENART, Jocelyne. Teorias da etnicidade. São Paulo: Fundação Editora da UNESP, 1998. p. 188. CUNHA, Maria Manuela Ligeti Carneira da. Cultura com aspas. São Paulo: Cosacnaify, 2009. p. 253. SAHLINS, Marshall. Adeus aos tristes trópicos: a etnografia no contexto da moderna história mundial. In: Cultura na prática. Rio de Janeiro: UFRJ, 2007. p. 520.

54 José Agostinho Pinheiro veio de Portugal para o Ceará em 1789 com o capitão-mor Luiz da Motta Féo e Torres. Cf. De Manuel Ignácio de Sampaio ao Marquês de Aguiar. Fortaleza, 19 de agosto de 1816. AN, AA, IJJ9 168. Joaquim Lopes de Abreu, português, é apontado como um dos fundadores do povoado de Maranguape. No fim do século XVIII já possuía terras na região. Cf. MATOS, Pedro Gomes de. Capistrano de Abreu: vida e obra de um grande historiador. Fortaleza: Batista Fontenele, 1953. p. 35-39. MATOS, Pedro Gomes de. Maranguape, Ceará (aspectos histórico-geográficos). Revista do Instituto do Ceará, Fortaleza, tomo LXXVII, p. 111, 1963. 
remetendo ao sentido político do antilusitanismo que marcou o início dos oitocentos, como aponta Robert Rowland ${ }^{55}$ e os boatos difundidos em 1821. As "palavras indiscretas" registradas em outros documentos podem ter sido ações de brasileiros não-índios - brancos ou mestiços - contrários aos portugueses e que buscavam insuflar os indígenas. Mas, mesmo que a revolta tenha sido inicialmente incitada pelos extranaturais, os índios tinham suas próprias demandas, como resistir à já sentida tomada de suas terras, pedir o retorno de seu rei e temer uma nova escravidão.

Daí se explicava claramente os gritos pela libertação dos cativos, que aconteceu mais de 60 anos depois. No início do século XIX, mesmo proibida, escravidão era a forma como os índios comumente definiam o abuso na exploração de sua mão de obra. Contudo, falar em "liberdade dos escravos" poderia provocar interpretações muito amplas. É possível que todas essas notícias partissem de exageros provenientes da situação conturbada deste contexto, fazendo circular histórias contraditórias. Todavia, a própria ebulição desses temores já revela a tensão que também perpassava pela população indígena atenta à conjuntura política do período.

Imediatamente após a notícia do tumulto, o governo passou ordens para que os moradores de localidades próximas a Maranguape fossem armados, atuando juntos a uma expedição de combate aos insurgentes, comandada pelo capitão-mor Marcos Antônio Brício ${ }^{56}$. Compondo a tropa de combate, estavam as ordenanças dos índios da vila de Arronches, que passou a ser a base das operações. Para lá

55 ROWLAND, Robert. Patriotismo, povo e ódio aos portugueses: notas sobre a construção da identidade nacional no Brasil independente. In: JANCSÓ, István (org.). Brasil: formação do estado e da nação. São Paulo: Hucitec, 2003. p. 384-385.

56 Barão de Jaguary, nascido em 1800 em São Luís do Maranhão, foi sócio do Instituto Histórico e Geográfico Brasileiro, deputado pelo Ceará entre 1826 e 1829, comandante superior da guarda nacional e diretor dos índios do Pará. Cf. VASCONCELOS, Rodolfo Smith de; VASCONCELOS, Jaime Smith de. Arquivo nobiliárquico brasileiro. Lausana: Imprimerie la Concorde, 1918. p. 233. 
também se dirigiu o ouvidor interino, responsável pelas devassas ${ }^{57}$. Em menos de cinco dias, vários revoltosos já haviam sido capturados e enviados presos a Fortaleza e já se autorizava a dispensa de tropas supérfluas, inclusive do próprio comandante Brício ${ }^{58}$. As notícias transmitidas pela documentação revelam o sucesso da expedição, bem como a importância dada ao evento pelo governo da província e os risco que tais índios amotinados representavam, especialmente para os moradores próximos. Estes últimos, antes vistos como promovedores da discórdia, passaram a ser agentes da repressão contra os revoltosos e protegidos pela Junta Governativa. Destaca-se também a tropa de índios de Arronches, membros da mesma comunidade dos de Maranguape e fiéis às lideranças provinciais, exemplo da heterogeneidade de visões e posicionamentos em um mesmo grupo indígena, composto tanto de oficiais e soldados quanto de agricultores comuns.

Alguns ofícios de 30 de setembro sugerem que tenha havido envolvimento de índios de Maranguape com os de outras vilas, além da já citada suspeita em relação ao comandante Manuel do Nascimento, de Monte-mor Novo. Nesse dia foi aceito um pedido de perdão de índios presos em Soure, mas que deveriam ser, a partir de então, vigiados pelo capitão-mor ${ }^{59}$. O governo também noticiou ao coronel de Granja, Francisco Carvalho Mota, sobre alguns fugitivos que teriam se dirigido a Viçosa (a uma distância de $270 \mathrm{~km}$ ), ordenando que os prendessem, evitando uma presumível aliança com os que se insurgiam contra o vigário Felipe Mariz ${ }^{60}$. Não é possível confirmar

57 De Francisco Gonçalves Ferreira Magalhães a Marcos Antônio Brício. Fortaleza, 24 de setembro de 1822. APEC, GC, livro 98, p. 119v.

58 De Francisco Gonçalves Ferreira Magalhães a Marcos Antônio Brício. Fortaleza, 28 de setembro de 1822. APEC, GC, livro 98, p. 122v. De Francisco Gonçalves Ferreira Magalhães a Marcos Antônio Brício. Fortaleza, 30 de setembro de 1822. APEC, GC, livro 98, p. 123v.

59 De Francisco Gonçalves Ferreira Magalhães a Francisco da Costa Lira. Fortaleza, 30 de setembro de 1822. APEC, GC, livro 98, p. 124v.

60 De Francisco Gonçalves Ferreira Magalhães a Francisco Carvalho Mota. Fortaleza, 30 de setembro de 1822. APEC, GC, livro 98, p. 125. 
se realmente havia intenções, por parte dos índios de diferentes lugares, em formar ações de resistência coordenada - até porque os de Arronches integravam as tropas expedicionárias -, mas é provável que a repressão do governo fora tamanha que muitos devem ter procurado refúgio em outros lugares.

As tropas formadas pelo governo controlaram a situação em Maranguape já no início do mês seguinte, a contar pelos registros sobre os presos acusados também de "vários furtos de importância" e da "destruição do sítio da índia Maria”. No dia 7, foi produzida uma devassa com uma relação dos índios capturados e os que não coubessem na alçada da Justiça da província do Ceará deveriam ser "remetidos com a culpa para a Relação de Pernambuco"61.

Com o conflito já terminado, a junta de governo provisório agradeceu ao vigário de Arronches por ter negado pagamento "pelos mantimentos que forneceu aos índios reunidos nessa vila e milicianos quando aconteceu o tumulto de Maranguape". Reconhecia o patriotismo do religioso, "que foi mais uma prova de quanto tem a prestar-se ao bem público todas as vezes que se lhe oferece a ocasião de ser útil"62. O reverenciado religioso era Amaro Joaquim de Moraes e Castro, o mesmo que, três anos antes, havia sido denunciado pelos índios de Arronches ao bispado de Olinda por extorsão e chamado de criminoso pela junta administrativa que, em 1820, governava o Ceará antes da chegada de Francisco Alberto Rubim. Curiosamente, um dos membros do governo, à época, era Joaquim Lopes de Abreu, alvo

61 De Francisco Gonçalves Ferreira Magalhães a Jacinto Fernandes de Araújo. Fortaleza, 2 de outubro de 1822. APEC, GC, livro 98, p. 127v. De Francisco Gonçalves Ferreira Magalhães a Vitoriano Alves de Souza. Fortaleza, 4 de outubro de 1822. APEC, GC, livro 98, p. 127. De Francisco Gonçalves Ferreira Magalhães a Vitoriano Alves de Souza. Fortaleza, 5 de outubro de 1822. APEC, GC, livro 98, p. 129. De Francisco Gonçalves Ferreira Magalhães a Jacinto Fernandes de Araújo. Fortaleza, 7 de outubro de 1822. APEC, GC, livro 98, p. 133v. De Francisco Gonçalves Ferreira Magalhães a Jacinto Fernandes de Araújo. Fortaleza, 9 de outubro de 1822. APEC, GC, livro 98, p. 138v.

62 De Francisco Gonçalves Ferreira Magalhães a Amaro Joaquim de Moraes e Castro. Fortaleza, 11 de outubro de 1822. APEC, GC, livro 98, p. 141v. 
dos índios no início das manifestações ${ }^{63}$. A mudança tão rápida nas qualificações do padre Amaro tinha provável relação com a necessidade em refazer sua imagem perante Abreu, mas, principalmente, diante dos índios de sua vila, que primeiro o haviam incriminado e que poderiam, na nova situação, colaborar com seu novo prestígio de patriota.

\section{Senhores do Brasil, escória da humanidade}

Já os revoltosos de Maranguape não tiveram a mesma sorte. Mesmo com a promessa do ano anterior de que tudo seria feito pelo governo para o bem dos índios, não escaparam das prisões e da violenta repressão ${ }^{64}$. Sua situação mudou apenas em fevereiro de 1823, com a consolidação da independência: presos pela oposição aos portugueses, foram soltos pela mesma razão. Na sessão do dia 13, a então junta provisória que comandava o Ceará decidiu soltar os presos "pelos movimentos da povoação de Maranguape, e dar-se imediatamente parte a Sua Majestade Real do procedimento do governo, visto que o seu único crime era defender a independência ${ }^{65}$.

Na mesma ocasião, o novo governo cearense, contrário às Cortes de Lisboa e adepto da independência liderada por dom Pedro I, produziu um relato ao monarca contando todos os acontecimentos que levaram à prisão dos índios e constando, inclusive, um abaixo-assinado de 21 indígenas envolvidos. As lideranças da província reconheciam a "injustiça com que foram presos, e até cruelmente açoi-

63 De Adriano José Leal, Francisco Xavier Torres e Joaquim Lopes de Abreu a Antônio Gomes Coelho. Fortaleza, 12 de fevereiro de 1820. APEC, GC, livro 30, p. 110v. Cf. COSTA, João Paulo Peixoto. Op. Cit., p. 159.

64 Geraldo Nobre se refere a um documento de 23 setembro de 1822 dando conta de que os índios José da Silva e Antônio da Silva foram açoitados no tronco pelo agente de política de Aquiraz, juntamente com alguns escravos, mas que não constava seus crimes ou se ao menos eram de Maranguape. Cf. NOBRE, Geraldo. Op. Cit., p. 317-318.

65 Sessão da Junta Provisória de Governo do Ceará. Fortaleza, 13 de fevereiro de 1823. APEC, GC, livro 32 , p. 63v. 
tados os índios da serra de Maranguape, tudo por cabala de europeus e brasileiros degenerados"66. Como se afirma no texto, os índios solicitaram sua soltura e o perdão real para os membros do governo que haviam destituído seus antigos algozes. Liderados por José Pereira Filgueiras, aproveitaram a comunicação para denunciar os abusos de seus antecessores.

Segundo eles, investigaram o caso assim que se compôs a nova administração da província e concluíram que se tratava do "antigo rancor da prepotência de alguns inimigos da causa do Brasil contra os miseráveis queixosos”. Comovidos pelos açoites que os índios sofreram a mando do capitão-mor Brício, "sensibilizados com a horribilidade de semelhante tirania e despotismo", o governo pôs "em liberdade os infelizes capturados”. Há na argumentação uma clara oposição entre "tirania" e "liberdade", representadas pela repressão do antigo governo - simpatizante do vintismo - contra a soltura promovida pelos adeptos da independência. O presidente Filgueiras e seus companheiros, imbuídos de antilusitanismo, percebiam na ocasião uma oportunidade de consolidar sua posição na província e imagem perante o rei, além de firmar sua aliança com a população indígen $a^{67}$. O texto, como destaca Maico Xavier, também é expressão dos conflitos entre diferentes grupos políticos no Ceará ${ }^{68}$.

66 De Jose Pereira Filgueiras, Joaquim Felício Pinto de Almeida e Castro e Francisco Fernandes Vieira a José Bonifácio de Andrada e Silva. Fortaleza, 25 de fevereiro de 1823. AN, série Justiça (AI), IJ ${ }^{1}$ 719. Salvo indicação em contrário, as citações nos próximos parágrafos pertencem a esse documento. Agradeço a Maico Oliveira Xavier pela cessão da cópia digitalizada do documento.

67 Indispensáveis como força de trabalho e militar, os índios se mostraram importantes aliados do governo liderado por José Pereira Filgueiras e Tristão Gonçalves de Alencar Araripe, atuando na deposição da antiga junta vintista, opondo-se à elite política de Fortaleza e em outros conflitos posteriores.

68 XAVIER, Maico Oliveira. Extintos no discurso oficial, vivos no cenário social: os índios do Ceará no período do império do Brasil - trabalho, terras e identidades indígenas em questão. Tese (Doutorado) - Universidade Federal do Ceará, 2015. p. 88. 
Em seguida, passaram a relatar o acontecido a partir da versão repassada pelos próprios índios ${ }^{69}$. Inicialmente, abordaram a importância do "direito de propriedade individual" e tudo o que a ele se opusesse era considerado "transtorno da sociedade; é perturbar a ordem; elevar uma subversão universal”. Por meio do Diretório, "dom José I, de gloriosa memória, deu liberdade aos índios cativos, [...] e lhes mandou assinar terras jamais alienáveis para sua moradia”. Desde a libertação de Pernambuco dos holandeses e da expulsão dos franceses do Rio de Janeiro e do Maranhão, os índios já haviam mostrado "aquela corajosa fidelidade que distingue o brasileiro", com destaque para Mel Redondo, antiga liderança. Apesar dos ferros e humilhações, "jamais deixaram de ser fiéis ao seu soberano, [...] não tendo nas mãos outras armas mais que o arco e que a fecha”.

Muitos elementos argumentativos ressaltam a convivência de aspectos referentes ao Antigo Regime e outros ao novo momento vivido no Brasil. A ênfase à liberdade e ao direito à propriedade dos índios, identificados como "brasileiros", denota o caráter liberal do posicionamento dos autores do texto. Ao mesmo tempo, tudo isso tinha como base medidas que remetiam ao período pombalino e a contextos bem mais antigos presentes na memória indígena. Elementos da cultura política dos índios, o Diretório ainda em vigor no Ceará e a histórica relação de vassalagem entre essa população e a Coroa portuguesa foram utilizados para justificar os direitos individuais indígenas no Brasil recém-independente. A própria forma "meritória" de se relatar a fidelidade dos índios, mais do que simples mistura entre "arcaico" e "moderno", é um traço da tradição absolutista operacionalizada em um novo contexto liberal.

69 Relato redigido por José Rodrigues de Souza com abaixo-assinado dos índios presos pelo motim de Maranguape. Fortaleza, 13 de fevereiro de 1823. Anexo ao ofício de José Pereira Filgueiras, Joaquim Felício Pinto de Almeida e Castro e Francisco Fernandes Vieira a José Bonifácio de Andrada e Silva. Fortaleza, 25 de fevereiro de 1823. AN, AI, IJ ${ }^{1} 719$. Salvo indicação em contrário, as citações nos próximos parágrafos pertencem a esse documento. 
Maico Xavier também observa que, se a questão da propriedade foi lembrada, é porque elas estavam sendo invadidas ${ }^{70}$, como se reclamara desde o início dos conflitos em 1821. De acordo com o relato,

Joaquim Lopes de Abreu, rico europeu, pelo direito da força, tem usurpado as diminutíssimas terras dos índios, os senhores do Brasil, território imenso. No apertado canto da povoação de Maranguape entrou como conquistador, tomando suas insignificantes possessões. E da mesma sorte José Agostinho Pinheiro [também nascido em Portugal], a título de data comprada a um usurpador como ele, não só se tem assenhorado [sic] da linha da serra de Maranguape, como já desc[ia] aquém dela. Há cento e quatorze anos estas terras foram dadas aos índios, mas os índios eram reputados como a escória da humanidade. Seus clamores e seus gemidos apenas se ouviam no recinto de suas humildes choupanas. Prevalecia a violência e a força.

As razões apresentadas da indignação dos índios eram muito antigas e mostram que os alvos não foram escolhidos aleatoriamente. Sendo portugueses e usurpadores de terras, tal associação denota o início do antilusitanismo indígena tão marcante nos conflitos liberais da década de 1820. Mas não é correto afirmar, como faz Xavier, que o "período pré-independência” é descrito como "tempo de não liberdade aos índios" retório, como o próprio relato asseverou, mesmo que tal condição fosse sempre desrespeitada. O que Filgueiras buscava argumentar era que os autores de tais tiranias eram os portugueses, vistos neste contexto como inimigos da liberdade.

Só após estas explicações é que o acontecimento é descrito. De acordo com o depoimento dos índios, em setembro de 1822 souberam de proclamações de dom Pedro I que tomavam "europeus por inimigos da nação brasileira", que "ao longe se forjavam grilhões para nos prender" e que "dentro em três meses seriam escravos". A partir daí, iniciaram sua ação:

70 XAVIER, Maico Oliveira. Op. Cit. p. 90.

71 Ibidem, p. 92. 
Os índios alvoroçados, lembrados dos seus ferros antigos, pegarão dos seus arcos e das suas flechas na noite do dia 22 de setembro, convida[ram] os habitantes a vingar a sua liberdade debaixo dos auspícios d'El Rei [?] Defensor do Brasil. [Fizeram] retumbar nos ares seus Nomes Augustos, a sua independência política. Corre[ram] à casa de José Agostinho Pinheiro para saber se assinava a causa, assim como já tinham feito aos demais europeus da povoação. Não derrama[ram] uma só gota de sangue, e nem maltrata[ram] a pessoa alguma; e se arromba[ram] as portas de seu diretor foi somente para saber-se do seu partido. Concorreu o povo em massa [?] para a casa de Joaquim Lopes de Abreu, não para ofendê-lo, sim para expulsá-lo para fora das suas usurpações. Foi então que apareceu um indigno e leve furto.

Pela versão dos índios, o acontecimento tem aspecto bem diferente do "motim" reprimido pelo governo da época. Por meio dos recursos linguísticos dos autores do relato, a ação indígena é alçada a um novo patamar: como observa Xavier, o que antes era tido como crime de amotinação passou a ser qualificado como "luta pela liberdade"72. Mais uma vez, a oposição entre a independência do Brasil e a escravidão de Portugal é evidenciada; associadas, respectivamente, à ação dos índios e à presença usurpadora de Abreu. A aliança entre o governo de Filgueiras e os índios também se expressa por compartilhar de uma versão que difere em diversos aspectos do que reproduzira a antiga junta provisória do Ceará. Na ótica indígena, o alvoroço e até mesmo a invasão à casa de Abreu ocorreram por uma causa justa e sem a barbárie com que havia sido encarada. O "leve furto" - antes tido como de "importância" - não manchara suas atitudes feitas em nome do rei, da independência e de sua liberdade. Diante dessa importante aliança, o novo governo agregava forças contra a elite das regiões próximas a Fortaleza e os adeptos do constitucionalismo português. Por isso, seu relato é um raro registro de uma autoridade não-indígena que classifica uma ação dos índios como "política".

Em contrapartida, Filgueiras contou que o antigo governo, "adorador das Cortes de Lisboa, [...] à independência chamou revolta e roubo". Na repressão, Marcos Antônio Brício, à frente de sua tropa,

72 Ibidem, p. 93. 
havia garantido a "segurança individual e de propriedade" dos índios, o que fez com que devolvessem as roupas e legumes que roubaram, "que se julgaram pequenos diante" do que já se usurpara deles. Entretanto, o "oficial infame violou a sua palavra; mandou passar roda de pau aos homens" e palmatória nas mulheres, "despotismo tão horroroso". Novamente, o antigo governo é associado ao constitucionalismo vintista e, consequentemente, a atos de despotismo. A novidade é que Brício, na verdade, enganara os índios que, segundo eles, nada haviam feito além de buscar garantir sua liberdade e obedecer às proclamações do imperador.

$\mathrm{Na}$ devassa que se seguiu após as prisões, o juiz e os escrivães responsáveis pelo julgamento eram todos portugueses que acreditavam que "os brasileiros deveriam ser escravos", como conta o relato. "Em questões de independência do Brasil, como foi a dos suplentes, não se deveriam admitir testemunhas inimigas [...]. Tudo, porém, se fez. Os europeus juraram, os corcundas juraram, os inimigos juraram". Como resultado, os índios teriam sido sentenciados "somente por serem brasileiros, amantes da causa da nossa independência e adesão à Majestade Augusta do Imortal Imperador do Brasil, nosso Protetor; e ainda agora gem[iam] os suplicantes nas masmorras como mártires da pátria". Diante de tal "injustiça" da "prepotência do despotismo", os índios pediram para serem perdoados, já que "só a independência do Brasil" foi o "objeto de perdição destes infelizes brasileiros acabrunhados pelos europeus, e por americanos degenerados, escravos vis desses senhores absolutos". O perdão de dom Pedro I foi finalmente obtido no dia $1^{0}$ de julho de $1823^{73}$.

Mesmo que pareça precipitado crer que os índios realmente aderiram à independência do Brasil, sua luta por respeito às garantias de terra e liberdade tinham conexão direta com os eventos políticos que culminaram com a separação política brasileira e com os conflitos internos na província. Ao contrário do que acredita Xavier, a ação indí-

73 Sessão da Junta do Governo Provisório da Província. Fortaleza, 18 de agosto de 1823. APEC, fundo Governo da Província (GP), série Junta do Governo Provisório (AJ), p. 37v. 
gena em defesa de prerrogativas e contra a exploração não se opunha à "causa da independência" e lutar por ela não era o mesmo que agir pelos interesses dos governantes ${ }^{74}$. Seus antigos inimigos, a elite das regiões no entorno de Fortaleza, derrubaram o último governador da capitania e simpatizaram com o constitucionalismo de Lisboa, que defendia a descentralização do poder no império. Além da ameaça da ambição dos proprietários, os índios também sabiam que o movimento vintista submetera dom João VI.

$\mathrm{O}$ antilusitanismo indígena, portanto, nasceu de sua luta pela liberdade, pela posse de seus territórios e contra a violência sofrida neste contexto. A tradicional defesa da Coroa, que garantira estes direitos e que passava a ser brasileira, era expressão da expectativa de reciprocidade e de justiça. O medo da escravidão, que poderia ressurgir com a constituição de Portugal, não estava baseado em meros boatos, mas nas práticas contra os índios de Maranguape. Em contrapartida, o novo governo os libertou e os enalteceu enquanto "brasileiros mártires da pátria”, em oposição aos inimigos nascidos no Brasil, chamados de "americanos degenerados". Por esse apoio, os índios dessa serra - e, consequentemente, de outras vilas e povoações do Ceará - passaram a ver a independência do Brasil como um movimento em prol de sua liberdade.

A ação liderada por Pereira Filgueiras não foi apenas um ato de altruísmo, mas, principalmente, uma forma de se aproximar dos bons olhos e ouvidos de dom Pedro I. Segundo Lúcia Neves, as tensões sociais "contribuíram para situar d. Pedro numa posição privilegiada, como fiador de uma ordem ameaçada"75, que passou a ser o símbolo dos "brasileiros" independentes. Além disso, a soltura dos indígenas, o subsequente comunicado a dom Pedro I e o perdão régio mostram

74 XAVIER, Maico Oliveira. Op. Cit., p. 96-97.

75 NEVES, Lúcia Maria Bastos Pereira das. Estado e política na independência. In: GRINBERG, Keila; SALLES, Ricardo (org.). O Brasil Imperial: 1808-1831. v. 1. Rio de Janeiro: Civilização Brasileira, 2009. p. 128. 
que as elites políticas no Ceará não poderiam fechar os olhos diante da atuação das camadas subalternas.

Segundo Filgueira, em outro relato dirigido a José Bonifácio, em fevereiro de 1823, os antigos membros da extinta junta de governo provisório José Raimundo Passos de Porbém Barbosa e Mariano Gomes da Silva buscaram revoltar os índios de Monte-mor Velho, Messejana, Arronches e Soure em prol das Cortes de Lisboa contra a independência do Brasil. Não teriam tido sucesso, pois, segundo Filgueiras, apesar de possuírem um "gênio servil e acabrunhado", os índios não deixavam de "suspirar pela sua liberdade". Os nativos de Maranguape, que costumavam sofrer nas mãos dos diretores, "portugueses imperiosos", haviam sido acossados tão barbaramente pelo governo que fora impossível a Barbosa e Silva conseguirem sua adesão.

Armados de arcos e de flechas este povo miserável posto em armas torna-se tremendo. Com proclamações, e um pouco de docilidade, assenhoreei-me, com o tenente coronel Bezerra, dos ânimos desses desgraçados americanos ${ }^{76}$.

O raciocínio contraditório de Filgueiras reconhece o poder não só das armas, mas também da ânsia dos índios em garantir seu estatuto de homens livres, que se revelou na rejeição aos opressores dos manifestantes de Maranguape. Entretanto, a fidelidade demonstrada não foi necessariamente decorrente das proclamações e docilidade do capitão-mor, mas se dirigia ao imperador do novo país que havia lhes concedido perdão.

Ao comentar acontecimentos semelhantes no Pará, André Roberto Machado afirma que "o grito de morte aos portugueses" bradado pelos indígenas "tinha a sua motivação no desejo de alijar do poder os homens da velha ordem que os oprimia, especialmente através do trabalho compulsório, o que, por extensão, atingia também a indiví-

76 De José Pereira Filgueiras a José Bonifácio de Andrada e Silva. Fortaleza, 20 de fevereiro de 1823. AN, série Confederação do Equador (IN), caixa 742, pacote 1. 
duos de notável posição nascidos na América"77. Segundo o autor, os índios em território paraense "passaram a reivindicar para si garantias e direitos aprovados nas Cortes de Lisboa, numa lógica que fazia a sua antiga condição de vassalos do rei de Portugal transformar-se no status de cidadão"78. Instrumentalizavam, portanto, o liberalismo em prol de suas demandas.

Os índios no Ceará, no mesmo período, também basearam sua liberdade e posse da terra na tradicional relação de vassalagem com a Coroa portuguesa. Mas sua leitura do constitucionalismo lusitano foi inversa à dos índios no Pará: nessa conjuntura, como aponta a historiografia, ${ }^{79}$ os portugueses significavam uma "nova ordem", ou seja, um mundo "liberal" que atacava o rei e ameaçava suas antigas garantias. Por isso que não existia "nada mais uniforme nos levantes feitos por esses indígenas do que o fato de eles se apresentarem como representantes do Imperador" ${ }^{\prime \prime}$. Ainda que tenham passado a se referir ao Antigo Regime a partir de uma leitura liberal, a ordem que os índios do Ceará queriam e defendiam era, de fato, a velha, que os tornara súditos livres da escravidão.

\section{O vigário Felipe Benício Marize os índios de Viçosa}

Em meio aos fatos que acometeram Maranguape, outras notícias de distúrbios ecoaram do outro lado do Ceará, na serra da Ibiapaba. Durante uma audiência com moradores de Viçosa, realizada no final de março de 1822, chegaram às mãos dos governadores provisórios

77 MACHADO, André Roberto de Arruda. Op. Cit., p. 225.

78 MACHADO, André Roberto de Arruda. O Conselho Geral da Província do Pará e a definição da política indigenista no império do Brasil (1829-1831). Almanack, n. 10, p. 445, 2015.

79 Cf. MAXWELL, Kenneth. Por que o Brasil foi diferente? O contexto da independência. In: MOTA,

Carlos Guilherme (org.). Viagem incompleta: a experiência brasileira. São Paulo: Editora SENAC, 2000. p. 189. MOTA, Carlos Guilherme. Ideias de Brasil: formação e problemas (1817-1850). In: . (org.). Viagem incompleta: a experiência brasileira. São Paulo: Editora SENAC, 2000.

p. 202-205.

80 MACHADO, André Roberto de Arruda. Op. Cit., p. 262. 
queixas contra o vigário da vila, Felipe de Souza Mariz. Natural do Icó, ele estudara no Seminário de Olinda e, segundo Washington Vieira, lutara contra os liberais durante a Revolução Pernambucana de 1817. Dois anos depois, tomara posse como vigário colado da freguesia de Nossa Senhora da Assunção da Vila Viçosa Real ${ }^{81}$. Dado seu histórico de posicionamentos conservadores, eram suficientemente preocupantes as reclamações contra ele em um momento de tensões política e de estabelecimento das ideias liberais no Brasil e em Portugal.

Os registros não explicitam com clareza os motivos da denúncia contra o padre, mas atestam a repreensão que ele recebeu da junta provisória por ter tentado promover agitações entre os moradores de Viçosa, em sua maioria índios, "povos que ainda gem[iam] de baixo de um pesado jugo e cativeiro". Segundo o governo, a "glória do cidadão liberal" era "cooperar, manter e congregar os povos ignorantes para uma perfeita harmonia", mas "sua imprudência" fazia com que os habitantes da vila se mudassem para as vizinhas. Ao final da missiva, disseram esperar que o vigário Mariz se contivesse "nas suas paixões e arbitrariedades, para não passar pelas torturas que a lei impõe, porque esta somente reserva àqueles que são bons cidadãos" ${ }^{2}$.

As palavras do governo levam a crer que os primeiros queixosos recebidos em audiência eram índios. Outra autoridade repreendida foi o diretor de Viçosa, Antônio do Espírito Santo. A junta dizia saber que ele, "de mãos dadas com o reverendo vigário dessa vila", queria, "neste tempo liberal, aterrar os povos rústicos da mesma". Por isso recomendava que, caso os índios não quisessem cumprir suas obrigações, o diretor os deveria "castigar sem motivo de paixão". Era seu dever agir com "prudência, brandura, sem seguir outro caminho que

81 VIEIRA, Washington Luiz Peixoto. Personagens históricos: padre Felipe Benício Mariz (1780-1850) - Parte I. Opinion, abril de 2009. Disponível em: <http://iconacional.blogspot.com.br/2009/04/ personagens-historicos-padre-felipe.html>. Acesso em: 7 jul. 2015.

82 Da junta de governo provisório a Felipe Benício Mariz. Fortaleza, 20 de março de 1822. AN, AA, IJJ9 576, p. 196. 
desvaire da mestra liberdade justa, único meio de conter os povos em subordinação e perfeita harmonia"83.

Até aqui não há um dado claro que indique que as ações abusivas do padre e do diretor se relacionavam com os novos acontecimentos políticos no império português, como a reunião das Cortes em Lisboa e a preparação da nova constituição. Mas as referências nos dois registros aos "tempos liberais" e aos deveres dos cidadãos levam a supor que, em suas queixas, os índios viam ligações entre o recrudescimento das atitudes de Felipe Mariz e Antônio do Espírito Santo com este momento de retorno do rei e, nos anseios dos que ambicionavam se apoderar da mão de obra indígena, de possíveis anulações das antigas mercês que lhes haviam sido garantidas.

Ciente disso, a junta de governo escreveu à câmara de Viçosa, formada também por índios, sobre as representações contra o vigário Mariz "para que se contivesse nos destemperados procedimentos", exigindo que os vereadores repassassem qualquer informação a respeito do padre ${ }^{84}$. Apesar de os esforços dos governadores, outra representação "assinada por vários habitantes de Vila Viçosa” foi enviada no final de maio à junta, que encaminhou, por sua vez, a responsabilidade de dar providência ao ouvidor interino da comarca de Fortaleza para, com brevidade, "fazer cessar de uma vez tão odiosas questões"85. Poucos dias depois, o juiz ordinário de Granja, acompanhado de oficiais, marchou rumo à vila dos índios para tomar conhecimento dos fatos relatados na representação que versava "toda contra o vigário Benício" ${ }^{6}$. Depois de estar cerca de um mês em Viçosa averiguando os fatos, outra denúncia lhe foi remetida; nesse caso, a Junta determinou, caso as acusações fossem precedentes, que o juiz

83 Da junta de governo provisório a Antônio do Espírito Santo. Idem, p. 196v.

$84 \mathrm{Da}$ junta de governo provisório à câmara de Vila Viçosa. Fortaleza, 28 de março de 1822. Idem, p. 205.

85 De José de Castro e Silva a Adriano José Leal. Fortaleza, 30 de maio de 1822. APEC, GC, livro 98 , p. $58 \mathrm{v}$.

86 De José de Castro e Silva ao juiz ordinário de Granja. Fortaleza, 3 de junho de 1822. APEC, GC, livro 98, p. $61 \mathrm{v}$. 
deveria prender os "cabeças dessa perturbação" e remetê-los a Fortaleza ${ }^{87}$.

Talvez cansados da lentidão do governo e da impunidade contra seus agressores, os índios não mais esperaram os resultados de tantos ofícios e queixas e partiram para a rebelião. Já nas recomendações de julho é possível perceber que, de denunciantes, os índios poderiam passar a criminosos em potencial, na ótica do governo. $O$ ápice da revolta ocorreu, segundo Geraldo Nobre, entre 30 e 31 de julho na Vila Viçosa, "quando o agrupamento indígena expuls[ou] da freguesia o vigário Felipe Benício Mariz"88. A memória de Manoel Ximenes de Aragão, contemporâneo do conturbado período da independência e das revoltas liberais da década de 1820 , também relata a retirada à força do padre, na Ibiapaba:

Na Vila Viçosa, depois de estarem com seu pároco, que então era o padre Felipe Benício, debaixo de cerco dentro da igreja, por algum tempo, perdoaram-lhe a morte, mas botaram-no serra abaixo, montado no meio de uma cangalha, em uma besta velha piolhenta, depois de ter suportado muitos pescoções que lhe davam as cunhãs ${ }^{89}$.

Na versão de Antônio Bezerra, a partir de histórias que colheu em viagem pelo norte do Ceará no final do século XIX, a índia Dionísia teria esbofeteado o padre que, "depois de sofrer as mais revoltantes afrontas", foi obrigado a deixar a freguesia ${ }^{90}$. Como nota Maico Xavier, as mulheres - comumente castigadas e abusadas - aparecem de forma destacada nos dois relatos com participação marcante na expulsão de Mariz ${ }^{91}$. A ação radical das índias pode ter

87 Fortaleza, $1^{\circ}$ de julho de 1822 . Idem, p. $74 \mathrm{~V}$.

88 NOBRE, Geraldo. Op. Cit., p. 315.

89ARAGÃO, Manoel Ximenes de. As fases de minha vida: genealogia. Revista do Instituto do Ceará, Fortaleza, ano XXVII, p. 72, 1913.

90 BEZERRA, Antônio. Notas de viagem. Fortaleza: Imprensa Universitária, 1965. p. 177.

91 XAVIER, Maico Oliveira. Cabôcullos são os brancos: dinâmicas das relações socioculturais dos índios do termo da Vila Viçosa Real - século XIX. Dissertação (Mestrado) - Universidade Federal 
sido uma manifestação limite contra as agressões que sofriam e que não conseguiam pôr fim pelas vias legais. Também se conectava provavelmente com o momento político e, talvez, com alguma ação ou ideia que o religioso buscava impor aos índios.

Outros documentos também se referem ao banimento de Felipe Mariz, mas, diferente dos relatos mencionados acima, parte deles consta que teria ocorrido no povoado de Baepina. No diário de Freire Alemão, a partir de entrevistas que fez durante sua passagem na serra da Ibiapaba em 1860, há o registro das memórias dos índios José da Silva de Azevedo e Felipe Pereira sobre os acontecimentos. Segundo eles, indígenas saídos "das matas de São Pedro [de Baepina] 'expulsaram' o vigário e mais brancos" e, ao se aperceberem do ocorrido, as autoridades convocaram os "índios dos sítios vizinhos para se oporem”. Não houve mortes, mas o capitão-mor indígena Paulo Borges teria sido flechado ${ }^{92}$.

Em outro registro, a junta governativa respondeu em 6 de agosto de 1822 a uma correspondência do pároco da Serra dos Cocos (atual Ipueiras), Manuel Pacheco Pimentel, tratando do "arrojo que tiveram os índios da povoação de São Pedro fazendo sair o vigário e tomando conta da vila”. Incumbia-o de enviar um sacerdote no lugar de Felipe Mariz "para tomar conta da igreja” e convencer os "índios a voltarem para as suas casas". Foi autorizado a tomar todas as providências que achasse adequadas entre outras já estabelecidas, "sendo uma delas mandar retirar da freguesia o vigário colado até segunda ordem", mostrando que, ao menos provisoriamente, o padre Felipe não voltaria à Ibiapaba. Os manifestantes parecem ter sido apenas parcialmente vitoriosos, já que também era vontade da junta que Pimentel informasse os nomes dos culpados da expulsão para que pu-

do Ceará, 2010. p. 121.

92 Diário de Francisco Freire Alemão. Informações sobre os antigos agrupamentos indígenas nas redondezas de Viçosa. Vila Viçosa, 8 e 9 de dezembro de 1860. Biblioteca Nacional (BN), I-28, 8, 68. 
dessem "proceder contra os chefes desse desacato" a ajuda do juiz ordinário e capitão-mor de Viçosa ${ }^{94}$.

A ausência de Mariz deve também ter atingido Viçosa. A pesquisa de Maico Xavier se deparou com alguns livros de batismo da vila assinados pelo padre Felipe Benício ${ }^{95}$, que atendia as duas localidades indígenas. Em 9 de agosto, a junta provisória respondeu ao pedido do sargento-mor dos índios João da Costa da Anunciação de que fosse enviado um presbítero para sua freguesia, ordenando que conservasse os "povos em paz, ficando responsável ao governo por qualquer desordem que por eles sejam motivadas"96. Como discute Xavier, a manutenção da patente de Anunciação e a missão que recebeu mostram que o sargento-mor indígena não se envolvera diretamente com o motim. Assumindo um cargo militar, exercia a difícil tarefa de servir de ponte entre as determinações do governo e as demandas de sua comunidade ${ }^{97}$. Mesmo não tomando parte ativamente na insubordinação, atuou para que sua igreja não ficasse sem padre, provável preocupação dos índios de sua comunidade que atentaram não contra a religião, mas contra alguém que os afligia, agindo de igual forma ao flechado capitão-mor indígena Paulo Borges e aos outros convocados. Juntos eram expressão da heterogeneidade de visões e intenções que compunha as comunidades indígenas oitocentistas.

Mantendo-se na posição de liderança dos índios e ocupando patente nas forças armadas do império português, João da Costa da Anunciação permaneceu ileso diante da truculenta perseguição do governo do Ceará contra os envolvidos diretos na expulsão do padre. A força da repressão foi ainda maior pelo clima de tensão na província, que passava por um período de agitações populares em diversas

93 Da junta de governo provisório a Manoel Pacheco Pimentel. Fortaleza, 6 de agosto de 1822. AN, AA, IJJ9 576, p. 330.

94 Da junta de governo provisório ao juiz ordinário e capitão-mor de Vila Viçosa. Idem, p. 330v. 95 XAVIER, Maico Oliveira. Op. Cit., p. 120.

96 De José de Castro e Silva a João da Costa da Anunciação. Fortaleza, 9 de agosto de 1822. APEC,

GC, livro 98, p. 97v.

97 XAVIER, Maico Oliveira. Op. Cit., p. 121-122. 
partes de seu território. Em sessão da junta de governo provisório de 21 de agosto, os membros destacaram os tumultos decorrentes do decreto de 3 de junho (que convocara uma Assembleia Geral Constituinte e Legislativa composta por deputados provinciais) e "da instalação do primeiro governo provisório”. Segundo eles, o povo pegou em armas no Crato "e em toda região do Cariri”, assim como nas vilas do Aracati e em São Bernardo (atual Russas).

A respeito dos índios, mencionaram que estes estavam "inquietos por toda parte, e preparando-se”, como ocorria em Maranguape. As medidas para conter os atos de insubordinação deveriam ser rigorosas: para os de Viçosa, "cabeças de motim devem ser castigados não só para pagarem as penas dos seus delitos, como para exemplo de outros". Como já foi dito, o temor em relação a uma ação extremada dos indígenas era recorrente e, por isso, os nativos "das vilas imediatas a esta capital deve[riam] ser vigiados pelos seus diretores e particularmente por este governo", ordenando-os para "pôr em execução os termos e prática observada no seu Diretório". Pela proximidade que Soure, Arronches, Messejana, Monte-mor Novo e Monte-mor Velho tinham de Fortaleza, era preocupação do governo que se tomassem "todas as medidas que parecerem mais adequadas para manter a segurança e tranquilidade desta capital, assim como de toda a província" ${ }^{\prime 9}$.

Aqui, definitivamente, o foco da ação do governo já não era mais as ações arbitrárias de Mariz, quaisquer que tenham sido elas. Bem mais preocupante era o povo em armas, especialmente os de posição mais baixa da hierarquia social. A junta provisória já não se importava mais com os motivos dos índios de se queixar ou de usar a força, mesmo que não tivessem chegado a matar o padre, como aconteceu em outras localidades do Ceará, segundo Ximenes Aragão99. Diante de uma situação tão conturbada, a prioridade dos membros do governo era abafar os tumultos, evitar que contagiassem outros grupos

98 Sessão da junta de governo provisório. Fortaleza, 31 de agosto de 1822. APEC, GC, livro 32, p. 19v. 99 ARAGÃO, Manoel Ximenes de. Op. Cit., p. 72. 
e que seus efeitos chegassem a Fortaleza, medo que ascendeu com os eventos de Maranguape. Ou seja, maior ofensa do que mandar embora à força o vigário, foi ter feito isso em pleno momento de levante popular, durante os acontecimentos que culminaram na separação política brasileira. A punição imposta pela junta se utilizava de uma pedagogia típica das penas do Antigo Regime estudadas por Silvia Lara, que visava ser "afirmativa e exemplar". Entretanto, neste caso, o poder que buscavam afirmar não era o do soberano, mas o deles próprios $^{100}$. Destaca-se, também, a presença do Diretório como referência aos procedimentos em relação aos índios, mesmo em um período liberal, ainda que seus "termos e prática" fossem aplicados com mais ênfase no caráter punitivo.

Em 16 de setembro, foi comunicado ao padre Pimentel, da Serra dos Cocos, a nomeação do vigário forâneo de Fortaleza Francisco Urbano Pessoa de Albuquerque Montenegro "para servir de encomendado na freguesia de Vila Viçosa" ${ }^{\text {.101 }}$ Ao fim do mês, em meio à repressão aos distúrbios encabeçados pelos índios de Maranguape, as perseguições aos da Ibiapaba continuaram e, no dia 30, o governo ordenou ao coronel de Granja para que prendesse "os cabeças do motim urdido em Vila Viçosa contra o vigário e alguns empregados da mesma vila"102, confirmando que Felipe Benício Mariz não fora o único afetado pela fúria indígena. Comunicou-o também sobre a marcha dos fugitivos entre as serras de Maranguape e Ibiapaba ${ }^{103}$, ratificando o receio, há pouco mencionado, de que grupos de localidades diferentes influenciassem uns aos outros em atos contestatórios. Ao final do mês seguinte, os culpados foram definitivamente capturados, com o

100 LARA, Silvia Hunold. Op. Cit., p. 21.

101 De Francisco Gonçalves Ferreira Magalhães a Manoel Pacheco Pimentel. Fortaleza, 16 de setembro de 1822. APEC, GC, livro 98, p. 113v.

102 Sessão da junta de governo provisório. Fortaleza, 30 de setembro de 1822. APEC, GC, livro 32, p. $30 \mathrm{v}$.

103 De Francisco Gonçalves Ferreira Magalhães a Francisco Carvalho Mota. Fortaleza, 30 de setembro de 1822. APEC, GC, livro 98, p. 125v. 
envio do ouvidor Adriano José Leal para dar ordens acerca dos "procedimentos dos índios de Vila Viçosa” ${ }^{104}$.

Os súditos que eram antes amparados por dom João VI tornaram-se, enfim, rapidamente criminosos, perseguidos e condenados. O contexto conturbado e incerto da nova constituição portuguesa por mais que não tenha sido explicitamente citada - atingiu diretamente os índios da Ibiapaba, dando condições para a eclosão do tumulto que promoveram e de sua violenta repressão. A repercussão da expulsão do padre Felipe também não mencionou as vozes indígenas nos documentos, mas trouxe à tona outras formas de manifestações indígenas para além da palavra escrita. A revoltada índia Dionísia, o ileso sargento Anunciação e o flechado capitão Borges são expressões da heterogeneidade de visões, intenções e posicionamentos dos índios, ainda que de uma mesma comunidade. A intenção era afastar os não-índios de seu convívio, mas o papel desempenhado por eles indica também as mudanças que já começavam a ser perceptíveis. A atuação indígena contra o sacerdote e a repressão do governo, ambas violentas, eram frutos do momento de tensão e dos dilemas em torno do destino do império lusitano, do Brasil e deles próprios, sujeitos a novas leis, condições políticas e relações sociais.

\section{Bibliografia}

ALMEIDA, Maria Regina Celestino de. Comunidades indígenas e Estado nacional: histórias, memórias e identidades em construção (Rio de Janeiro e México - séculos XVIII e XIX). In: ABREU, Marta; SOIHET, Rachel; GONTIJO, Rebeca (org.). Cultura politica e leituras do passado: historiografia e ensino de História. Rio de Janeiro: Civilização Brasileira, 2007.

- O lugar dos índios na história entre múltiplos usos do passado: reflexões sobre cultura histórica e cultura política. In: SOIHET, Rachel; ALMEIDA, Maria Regina Celestino de; SÁ, Cecília; GONTIJO, Rebeca.

104 De José de Castro e Silva a Adriano José Leal. Fortaleza, 31 de outubro de 1822. APEC, GC, livro 98 , p. $156 \mathrm{v}$. 
Mitos, projeto e práticas políticas: memória e historiografia. Rio de Janeiro: Civilização Brasileira, 2009.

ARAGÃO, Manoel Ximenes de. As fases de minha vida: genealogia. Revista do Instituto do Ceará, Fortaleza, ano 27, p. 47-152, 1913.

BARICKMAN, Bert J. "Tame Indians", "wild heathens" and settlers in southern Bahia in the late eighteenth and early nineteenth centuries. The Americas, v. 51, n. 3, p.325-368, 1995.

BARTH, Fredrick. Grupos étnicos e suas fronteiras apud POUTIGNAT, Philippe; STREIFF-FENART, Jocelyne. Teorias da etnicidade. São Paulo: Fundação Editora da UNESP, 1998.

BEZERRA, Antônio. Notas de viagem. Fortaleza: Imprensa Universitária, 1965.

COSTA, João Paulo Peixoto. Disciplina e invenção: civilização e cotidiano indígena no Ceará. Teresina: EDUFPI, 2015.

CARVALHO, Marcus J. M. de. Os índios e o Ciclo das Insurreições Liberais em Pernambuco (1817-1848): ideologias e resistências. In: ALMEIDA, Luiz Sávio de. GALINDO, Marcos. Indios do Nordeste: temas e problemas. v. 3. Maceió: Edufal, 2002.

. Clientelismo e contestação: o envolvimento dos índios de Pernambuco nas brigas dos brancos na época da independência. In: MONTEIRO, John Manuel; AZEVEDO, Francisca Nogueira de. (org.). Confronto de culturas: confronto, resistência e transformação. São Paulo: Edusp, 1997. p. 329-342.

CUNHA, Maria Manuela Ligeti Carneira da. Cultura com aspas. São Paulo: Cosacnaify, 2009.

DANTAS, Beatriz; SAMPAIO, José Augusto; CARVALHO, Maria do Rosário. Os povos indígenas no nordeste brasileiro: um esboço histórico. In: CUNHA, Manuela Carneiro da. História dos índios no Brasil. São Paulo: Companhia das Letras, 1992.

DANTAS, Mariana Albuquerque. Dimensões da participação política indígena na formação do Estado nacional brasileiro: revoltas em Pernambuco e Alagoas (1817-1848). Tese (Doutorado em História) - Universidade Federal Fluminense, Niterói, 2015.

DARÓZ, Carlos Roberto Carvalho. A milícia em armas: o soldado brasileiro da guerra de independência. Revista Brasileira de História Militar, v. 4, n. 11, p. 41-42, 2013. 
FELIX, Keile Socorro Leite. Espíritos inflamados: a construção do Estado nacional brasileiro e os projetos políticos no Ceará (1817-1840). 2010. Dissertação (Mestrado) - Universidade Federal do Ceará, Fortaleza, 2010.

FERREIRA, Lorena de Mello. São Miguel de Barreiros: uma aldeia indígena no Império. Dissertação (Mestrado em História) - Universidade Federal de Pernambuco, Recife, 2006.

GARCIA, Elisa Frühauf. Dimensões da igualdade: os significados da condição indígena no processo de independência do Rio da Prata. In: Encontro Regional de História da Anpuh, 19., São Paulo. Anais... São Paulo: Anpuh, 2008.

GINZBURG, Carlo. Our words, and theirs: a reflexion on the historian's craft, today. In: FELLMAN, Susanna; RAHIKAINEN, Marjatta. Quest of theory, method and evidence. Cambridge: Cambridge Scholars Publishing, 2012.

GÓMEZ, Julio Sánchez. Invisibles y olvidados: indios e independencia de Brasil. Studia Historica. Historia Contemporánea, n. 27, p. 250-251, 2009.

GUERRA FILHO, Sérgio Armando Diniz. O povo e a guerra: participação das camadas populares nas lutas pela independência do Brasil na Bahia. Dissertação (Mestrado em História Social) - Universidade Federal da Bahia, Salvador, 2004.

LANGFUR, Hal. The forbidden lands: colonial identity, frontier violence, and the persistence of Brazil's Eastern indians, 1750-1830. Stanford: Stanford University Press, 2006.

LARA, Silvia Hunold. Introdução: ordenações filipinas. Livro V. São Paulo: Companhia das Letras, 1999.

LEMOS, Marcelo Sant'ana. O índio virou pó de café? A resistência dos índios Coroados de Valença frente à expansão cafeeira do Vale do Paraíba (1788-1836). Dissertação (Mestrado em História) - Universidade do Estado do Rio de Janeiro, Rio de Janeiro, 2004.

LOPES, Fátima Martins. Em nome da liberdade: as vilas de índio do Rio Grande do Norte sob o Diretório pombalino no século XVIII. Tese (Doutorado em História do Norte-Nordeste) - Universidade Federal de Pernambuco, Recife, 2005.

LOURENÇO, Jaqueline. Um espelho brasileiro: visões sobre os povos indígenas e a construção de uma simbologia nacional do Brasil (1808-1831). Dissertação (Mestrado em História Social) - Universidade de São Paulo, São Paulo, 2010. 
MACHADO, André Roberto de Arruda. O Conselho Geral da Província do Pará e a definição da política indigenista no império do Brasil (18291831). Almanack, n. 10, p. 437-464, 2015.

- A quebra da mola real das sociedades: a crise política do antigo regime português na província do Grão-Pará (1821-25). Tese (Doutorado) - Universidade de São Paulo, 2006.

MALHEIROS, Márcia. Homens da fronteira: índios e capuchinhos na ocupação dos Sertões do Leste, do Paraíba ou Goytacazes (séculos XVIII e XIX). Tese (Doutorado em História) - Universidade Federal Fluminense, Niterói, 2008.

MARINATO, Francieli Aparecida. Índios imperiais: os botocudos, os militares e a colonização do Rio Doce (Espírito Santo, 1824-1845). Dissertação (Mestrado em História Social das Relações Políticas) - Universidade Federal do Espírito Santo, Vitória, 2007.

MATOS, Pedro Gomes de. Capistrano de Abreu: vida e obra de um grande historiador. Fortaleza: Batista Fontenele, 1953.

MATOS, Pedro Gomes de. Maranguape, Ceará (aspectos histórico-geográficos). Revista do Instituto do Ceará, Fortaleza, tomo LXXVII, 1963.

MATTOS, Izabel Missagia. "Civilização" e "revolta": povos botocudos e indigenismo missionário na província de Minas. Tese (Doutorado em Ciências Sociais) - Universidade Estadual de Campinas, Campinas, 2002.

MAXWELL, Kenneth. Por que o Brasil foi diferente? O contexto da independência. In: MOTA, Carlos Guilherme (org.). Viagem incompleta: a experiência brasileira. São Paulo: Editora Senac, 2000.

MELO, Karina Moreira Ribeiro da Silva e. A aldeia de São Nicolau do Rio Pardo: histórias vividas por índios guaranis (séculos XVIII e XIX). Dissertação (Mestrado em História) - Universidade Federal do Rio Grande do Sul, Porto Alegre, 2011.

MOREIRA, Vânia Maria Losada. Autogoverno e economia moral dos índios: liberdade, territorialidade e trabalho (Espírito Santo, 1798-1845). Revista de História, n. 166, p. 223-243, 2012.

. Indianidade, territorialidade e cidadania no período pós-independência - Vila de Itaguaí, 1822-1836. Diálogos Latinoamericanos, n. 18, p. 1-17, 2011.

MOREL, Marco. Independência, vida e morte: os contatos com os Botocudo durante o Primeiro Reinado. Dimensões, v. 14, p. 91-113, 2002. 
MOTA, Carlos Guilherme. Ideias de Brasil: formação e problemas (18171850). In: . (org.). Viagem incompleta: a experiência brasileira. São Paulo: Editora SENAC, 2000. p. 202-205.

NEVES, Lúcia Maria Bastos Pereira das. Estado e política na independência. In: GRINBERG, Keila; SALLES, Ricardo (org.). O Brasil Imperial: 1808-1831. v. 1. Rio de Janeiro: Civilização Brasileira, 2009.

NOBRE, Geraldo. Os índios revoltosos na serra de Maranguape. Revista do Instituto do Ceará, Fortaleza, tomo CIX, p. 315-318, 1995.

OLIVEIRA, Almir Leal de. A construção do Estado nacional no Ceará na primeira metade do século XIX: autonomias locais, consensos políticos e projetos nacionais. In: OLIVEIRA, Almir Leal de; BARBOSA, Ivone Cordeiro (org.). Leis provinciais: Estado e cidadania (1835-1861). Tomo I. Fortaleza: INESP, 2009. p. 20-21.

PARAÍSO, Maria Hilda Baqueiro. O tempo da dor e do trabalho: a conquista dos territórios indígenas nos sertões do leste. Salvador: EDUFBA, 2014.

PERES, Natalia Sobrevilla. Introduction: identity and subalterns actors in the wars of independence. Estudios Interdisciplinarios de América Latina y el Caribe, Tel Aviv, v. 22, n. 1, p. 9-12, 2011.

PIMENTA, João Paulo Garrido. A independência do Brasil e o liberalismo português: um balanço da produção acadêmica. Revista de História Ibero-americana, Madri, v. 1, n. 1, 2008.

REGO, André de Almeida. Trajetórias de vidas rotas: terra, trabalho e identidade indígena na província da Bahia (1822-1862). Tese (Doutorado em História Social) - Universidade Federal da Bahia, Salvador, 2014.

RIBEIRO, Gladys Sabina. O desejo de liberdade e a participação de homens livres pobres e "de cor" na independência do Brasil. Caderno Cedes, Campinas, v. 22, n. 58, p. 29-30, 2002.

RIBEIRO, Gladys Sabina. A liberdade em construção: identidade nacional e conflitos antilusitanos no Primeiro Reinado. Tese (Doutorado) - Universidade Estadual de Campinas, Campinas, 1997.

RICCI, Magda Maria de Oliveira. Nas fronteiras da independência: um estudo sobre os significados da liberdade na região de Itu (1779-1822). Dissertação (Mestrado) - Universidade Estadual de Campinas, 1993.

ROWLAND, Robert. Patriotismo, povo e ódio aos portugueses: notas sobre a construção da identidade nacional no Brasil independente. In: JANCSÓ, István (org.). Brasil: formação do estado e da nação. São Paulo: 


\section{Hucitec, 2003.}

RUBIM, Braz da Costa. Memória sobre a revolução do Ceará em 1821. Revista do Instituto Histórico e Geográfico do Brasil, Rio de Janeiro, tomo XXIX, segunda parte, p. 206-207, 1866.

SAHLINS, Marshall. Adeus aos tristes trópicos: a etnografia no contexto da moderna história mundial. In: . Cultura na prática. Rio de Janeiro: Editora da UFRJ, 2007.

SANTOS, Raquel Dani Sobral. A construção do estatuto de cidadão para os índios do Grão-Pará (1808-1822). Dissertação (Mestrado em História Social) Universidade de São Paulo, São Paulo. 2013.

SILVA, Natalia Moreira da. Papel de indio: políticas indigenistas na província de Minas Gerais e Bahia na primeira metade dos oitocentos (1808-1845). Dissertação (Mestrado em História) - Universidade Federal de São João Del-Rei, São João Del-Rei, 2012.

SILVA, Tarcísio Glauco da. Junta de civilização e conquista dos índios e navegação do rio Doce: fronteiras, apropriação de espaços e conflitos (1808-1814). Tese (Doutorado História Social das Relações Políticas) - Universidade Federal do Espírito Santo, Vitória, 2006.

SOUZA, Almir Antônio de. Armas, pólvoras e chumbo: a expansão luso-brasileira e os indígenas do planalto meridional na primeira metade do século XIX. Tese (Doutorado em História) - Universidade Federal de Santa Catarina, Florianópolis, 2012.

SPOSITO, Fernanda. Nem cidadãos, nem brasileiros: indígenas na formação do Estado nacional brasileiro e conflitos na província de São Paulo (1822-1845). São Paulo: Alameda, 2006.

VARNHAGEN, Francisco Adolfo de. História da independência do Brasil até ao reconhecimento pela antiga metrópole, compreendendo, separadamente, a dos sucessos ocorridos em algumas províncias até essa data. Revista do Instituto Histórico e Geográfico Brasileiro, Rio de Janeiro, tomo LXXXIX, 1916.

VASCONCELOS, Rodolfo Smith de; VASCONCELOS, Jaime Smith de. Arquivo nobiliárquico brasileiro. Lausana: Imprimerie la Concorde, 1918.

VIEIRA, Washington Luiz Peixoto. Personagens históricos: padre Felipe Benício Mariz (1780-1850) - Parte I. Opinion, abril de 2009. Disponível em: <http://iconacional.blogspot.com.br/2009/04/personagens-historicos-padre-felipe.html>. Acesso em: 7 jul. 2015. 
XAVIER, Maico Oliveira. Cabôcullos são os brancos: dinâmicas das relações socioculturais dos índios do termo da Vila Viçosa Real - século XIX. Dissertação (Mestrado) - Universidade Federal do Ceará, 2010.

XAVIER, Maico Oliveira. Extintos no discurso oficial, vivos no cenário social: os índios do Ceará no período do império do Brasil - trabalho, terras e identidades indígenas em questão. Tese (Doutorado) - Universidade Federal do Ceará, 2015.

Recebido em: 11/04/2018 - Aprovado em: 29/11/2018 